\title{
Neurotransmitter Release at the Thalamocortical Synapse Instructs Barrel Formation But Not Axon Patterning in the Somatosensory Cortex
}

\author{
Nicolas Narboux-Nême, ${ }^{1,2,3}$ Alexis Evrard, ${ }^{4,8,9}$ Isabelle Ferezou, ${ }^{5}$ Reha S. Erzurumlu, ${ }^{6}$ Pascal S. Kaeser, ${ }^{7}$ Jeanne Lainé, $, 2,3$ \\ Jean Rossier, ${ }^{5}$ Nicole Ropert, ${ }^{4,8,9}$ Thomas C. Südhof, ${ }^{7}$ and Patricia Gaspar ${ }^{1,2,3}$ \\ ${ }^{1}$ Institut National de la Santé et de la Recherche Médicale, UMR-S 839, 75005 France, ${ }^{2}$ Université Pierre et Marie Curie, Paris, 75005, Paris, France, ${ }^{3}$ Institut \\ du Fer à Moulin, 17, rue du Fer à Moulin, 75005, Paris, France, ${ }^{4}$ Institut National de la Santé et de la Recherche Médicale, U603, Laboratory of \\ Neurophysiology and New Microscopies, 75006 Paris, France, ${ }^{5}$ CNRS, UMR 7637, Laboratoire de Neurobiologie, ESPCI ParisTech, 75005, Paris, France, \\ ${ }^{6}$ Department of Anatomy and Neurobiology, University of Maryland School of Medicine, Baltimore, Maryland 21201, ${ }^{7}$ Howard Hughes Medical Institute, \\ Stanford University, Stanford, California 94305-5453, ${ }^{8} \mathrm{CNRS}$, UMR 8154, Paris, France, and ${ }^{9}$ Université Paris Descartes, 75006, Paris, France
}

To assess the impact of synaptic neurotransmitter release on neural circuit development, we analyzed barrel cortex formation after thalamic or cortical ablation of RIM1 and RIM2 proteins, which control synaptic vesicle fusion. Thalamus-specific deletion of RIMs reduced neurotransmission efficacy by $67 \%$. A barrelless phenotype was found with a dissociation of effects on the presynaptic and postsynaptic cellular elements of the barrel. Presynaptically, thalamocortical axons formed a normal whisker map, whereas postsynaptically the cytoarchitecture of layer IV neurons was altered as spiny stellate neurons were evenly distributed and their dendritic trees were symmetric. Strikingly, cortex-specific deletion of the RIM genes did not modify barrel development. Adult mice with thalamic-specific RIM deletion showed a lack of activity-triggered immediate early gene expression and altered sensory-related behaviors. Thus, efficient synaptic release is required at thalamocortical but not at corticocortical synapses for building the whisker to barrel map and for efficient sensory function.

\section{Introduction}

Genetic alterations of synaptic transmission underlie a number of developmental disorders, such as autism spectrum disorders or mental retardation (Bourgeron, 2009). However, the role of hard-wired defects of neural circuits in these affections remains unclear. Neural activity is involved in neuronal network wiring but no visible change in brain development was observed upon abolishing synaptic release (Verhage et al., 2000; Molnár et al., 2002). Since neurotransmitters and electrical activity have direct effects on morphogenetic processes such as neuronal growth (Zhang and Poo, 2001), guidance (Hanson and Landmesser, 2004; Nicol et al., 2007), or gene transcription (Borodinsky et al., 2004), a large part of the developmental effects of neural activity could be independent of synaptic activity. However, the role of

Received Jan. 24, 2012; revised March 9, 2012; accepted March 15, 2012.

Author contributions: P.G. designed research; N.N.-N., A.E., I.F., R.S.E., J.L., and N.R. performed research; P.S.K., J.R., and T.C.S. contributed unpublished reagents/analytic tools; N.N.-N., A.E., I.F., R.S.E., J.L., and P.G. analyzed data; N.N.-N., A.E., I.F., R.S.E., N.R., T.C.S., and P.G. wrote the paper.

This work was supported by Institut National de la Santé et de la Recherche Médicale, Université Pierre et Marie Curie, the Fondation Jerome Lejeune, Domaine d'Intérêt Majeur Neurosciences Région île de France; Agence Nationale pour la Recherche (ANR605-neur-046), Ecole des Neurosciences de Paris and NIH/NINDS R01 NS039050 (R.S.E.). We thank Alexandra Rebsam for critical reading of the manuscript and Gaelle Angenard for technical help.

Correspondence should be addressed to Patricia Gaspar, INSERM U839, 17 rue du Fer à Moulin, 75005, Paris, France. E-mail: patricia.gaspar@inserm.fr.

I. Ferezou's present address: UNIC, CNRS, UPR-3293, 91198, Gif-Sur Yvette, France.

DOI:10.1523/JNEUROSCI.0343-12.2012

Copyright $\odot 2012$ the authors $\quad 0270-6474 / 12 / 326183-14 \$ 15.00 / 0$ synaptic release in later activity-dependent refinement of neural circuits could not be examined because of early lethality.

Neurotransmitter release is controlled by proteins that prime vesicles to the presynaptic active zone, where they control vesicle fusion following $\mathrm{Ca}^{2+}$ rise (Sudhof, 2004). Among these proteins, the Rab3 interacting molecules (RIM) family includes seven isoforms, two of which, RIM1 and RIM2, are expressed broadly in the brain (Schoch et al., 2006). RIM1 and RIM2 are central organizers of presynaptic release, interacting with a number of active zone proteins as well as synaptic vesicle proteins (Mittelstaedt et al., 2010). Loss of function studies revealed that RIMs are required for the docking of synaptic vesicles and for the assembly of calcium channels in the presynaptic active zone (Deng et al., 2011; Han et al., 2011; Kaeser et al., 2011). RIM1/ RIM2 double knock-out mice show a massive reduction in the priming and calcium-triggering of neurotransmitter release (Schoch et al., 2006; Kaeser et al., 2011).

Ablation of RIMs at selected synapses should allow determining the role of calcium-dependent neurotransmitter release on late phases of neural wiring. We used the rodent primary somatosensory barrel cortex as a model in which neural activity plays a role in sculpting barrels within the posteromedial barrel subfield (Erzurumlu and Kind, 2001; Wu et al., 2011). Barrels are columnar processing units that respond preferentially to the stimulation of individual whiskers. The development of a barrel is initiated by the clustering of thalamocortical (TC) axon terminals, followed by an arrangement of the cortical layer IV neurons 
and by the orientation of their dendrites toward incoming TC terminal arborizations (Wu et al., 2011). The formation of barrels over the first postnatal week depends on neural activity, with the involvement of both presynaptic and postsynaptic mechanisms (Iwasato et al., 2000; Hannan et al., 2001; Rebsam et al., 2002; Gheorghita et al., 2006; Lu et al., 2006; Ballester-Rosado et al., 2010).

Here we conditionally deleted all multidomain RIM isoforms in the thalamus causing a severe reduction in evoked release at the TC synapse. This did not alter the targeting and patterning of the TC afferents, but severely impaired the dendritic arbor orientation of target neurons in the somatosensory barrel cortex. In contrast, mice with a cortex-specific deletion of RIMs showed a normal barrel organization.

\section{Materials and Methods}

Animal breeding

RIM1 $1^{\text {flox/flox }}$-RIM2 flox/flox mice (Kaeser et al., 2008, 2011) were crossed to two different Cre mouse lines to obtain recombination in the thalamus and in the cerebral cortex. Breeding was performed on a mixed background $129 \mathrm{~Sv} \times \mathrm{C} 57 \mathrm{BL} / 6$. To minimize potential variation due to background issues, littermate controls of either sex were used for all the experiments and processed simultaneously with the recombined samples.

To obtain thalamic-specific recombination, the serotonin transporter (Sert) Cre mouse line was used. This is a knock-in of nls-Cre in the 5'UTR region of Sert (Sl6a4; Zhuang et al., 2005). In these mice, Cre is active in the ventrobasal thalamus (VB) from E15.5 (Narboux-Nême et al., 2008). Unexpectedly, some offspring of RIM1 flox/flox - RIM $2^{\text {flox/flox }}$ breeding with Sert ${ }^{\text {Cre }}$ strain gave rise to null alleles (RIM ${ }^{-}$allele), indicating occasional germline expression of Cre that needed to be controlled in all littermates. In our breeding we usually obtained: $\operatorname{Rim} 1^{\mathrm{f} /-} \operatorname{Rim} 2^{\mathrm{f} /-}$ $\mathrm{Sert}^{\text {cre/++}}$, which are referred to as RIM-DKO ${ }^{\text {Sert }}$, and $\operatorname{Rim} 1^{\mathrm{f} /-} \operatorname{Rim} 2^{\mathrm{f} /-}$ Sert ${ }^{+/+}, \operatorname{Rim} 1^{\mathrm{f} / \mathrm{f}}$ or $\operatorname{Rim} 2^{\mathrm{f} / \mathrm{f}}$, which are referred to as Controls (Ctrl). In their home cages, RIM-DKO ${ }^{\text {Sert }}$ could not be distinguished from their control littermates and showed normal survival rates.

For cortex-specific recombination, we used the Emx1-Cre mouse line, a knock-in of Cre in $3^{\prime}$ from the stop codon (Iwasato et al., 2000). In these mice, Cre is active in the glutamatergic cortical neurons and in glia but not in GABAergic neurons at E12.5 (Iwasato et al., 2000). Rim recombination with Emx1-Cre strain is referred to as RIM-DKO ${ }^{\mathrm{Emx} 1}$, and their littermates were used as controls. The RIM-DKO ${ }^{\mathrm{Emxl}}$ mice were smaller than their control littermates and all died around weaning.

We used the Tau ${ }^{\text {mGFP-nls-LacZ }}$ reporter mouse line to check recombination efficiency. This is a knock-in in the Tau gene of a construction containing a stop cassette flanked by loxP sites, a MARCKS sequence fused to the green fluorescent protein (GFP) and an IRES-NLS-LacZ cassette (Hippenmeyer et al., 2005). In the presence of Cre, neurons express a membrane-bound GFP and $\beta$-Galactosidase $(\beta$-Gal) in the nucleus.

Experiments were conducted in compliance with the standard ethical guidelines (European Community guidelines on the care and use of laboratory animals and French Agriculture and Forestry Ministry guidelines for handling animals).

Genotyping was done on tail lysates prepared by immersing tissue in $50 \mathrm{~mm} \mathrm{NaOH}$, at $95^{\circ} \mathrm{C}$ for $1 \mathrm{~h}$, and then neutralizing with $1 \mathrm{M}$ Tris- $\mathrm{HCl}$. PCRs were conducted as previously described (Kaeser et al., 2008, 2011).

\section{RIM1 and RIM2 quantitative PCR}

Brains from postnatal day 7 (P7, P0 being the day of birth) RIM$\mathrm{DKO}^{\text {Sert }}$, RIM-DKO ${ }^{\mathrm{Emxl}}$ and controls were dissected out and directly frozen on liquid nitrogen for $10 \mathrm{~s}$ and transferred to dry ice. The VB and somatosensory cortex were microdissected on $120 \mu \mathrm{m}$ cryostat section. RNAs were extracted from samples and genomic DNA was removed with "RNAqueous-Micro Kit" (Applied Biosystems). First-strand cDNA was synthesized by reverse transcription of $50 \mathrm{ng}$ of total RNA with Superscript-II reverse transcriptase (Invitrogen) according to standard protocols. Reverse transcriptase was omitted in some samples as negative control. Relative expression levels of RIM1 and RIM2 mRNA were determined by real time RT-PCR using Absolute SYBR Green Mix (ABgene) and a set of primers specific for the RIM1 and RIM2 floxed sequences. RIM expression was normalized to mouse CyclophilinB mRNA expression. Data were analyzed with the 2-DCt method (Livak and Schmittgen, 2001). Values are expressed as the mean of 3-5 separate experiments, each comprising triplicates.

\section{Tissue preparation}

Mice were killed by an overdose of xylazine $(1.92 \mathrm{mg} / \mathrm{kg}$ body weight, i.p.) and pentobarbital (100 mg/kg i.p.). They were perfused with $4 \%$ paraformaldehyde in phosphate buffer. Brains were dissected and either rinsed in PBS for cytochrome oxidase staining, or postfixed overnight at $4^{\circ} \mathrm{C}$. Brains were cryoprotected overnight in $30 \%$ sucrose in PBS at $4^{\circ} \mathrm{C}$ before sectioning at $60 \mu \mathrm{m}$ with a freezing microtome. To obtain tangential sections, cortices were dissected and flattened between two glass slides with spacers before postfixation.

\section{Histology}

The cytochrome oxidase (CO) staining of brain sections was conducted on free-floating sections. They were placed in the $\mathrm{CO}$ reaction solution (5 mg diaminobenzidine, $5 \mathrm{mg}$ cytochrome $\mathrm{C}, 0.4 \mathrm{~g}$ sucrose in $0.1 \mathrm{~mm}$ Tris, $\mathrm{pH} 7.6$ ) for $12-24 \mathrm{~h}$ at $37^{\circ} \mathrm{C}$.

Immunocytochemistry was performed on free-floating sections. They were incubated overnight at $4^{\circ} \mathrm{C}$ in appropriate primary antibodies including: rabbit polyclonal antibody (Ab) c-Fos (1:1000, Santa-Cruz Biotechnology), rabbit polyclonal Ab CDP/Cux1 (1:500, Santa-Cruz), rabbit polyclonal Ab $\beta$-Gal (1:5000, Rockland), mouse monoclonal Ab NeuN (1:1000, Millipore), rabbit polyclonal Sert (1:1000, Calbiochem), Guinea pig polyclonal Ab vGlut2 (1:2000, Millipore Bioscience Research Reagents). After several rinses, species-specific fluorescent secondary Ab ( $1: 500$ Invitrogen) were incubated for $2 \mathrm{~h}$, before mounting with Mowiol (Calbiochem). vGlut2 immunohistochemistry was preceded by a $10 \mathrm{~min}$ incubation in $50 \mathrm{~mm}$ sodium citrate at $97^{\circ} \mathrm{C}$. For peroxidase revelation of Sert, biotinylated anti-rabbit (1:300, Vector) followed by avidin-biotinperoxidase complex (1:400, GE Healthcare) was used before the diaminobenzidine reaction.

In situ hybridization was performed on free-floating frozen sections as described previously (Narboux-Nême et al., 2008). NBT/BCIP was used as blue substrate for in situ revelation. The following plasmids containing full-length cDNA were used: RIM1 (IMAGE:40047877) and RIM2 (IMAGE:4505661)

\section{Measures and cell counts}

Quantification of areas. vGlut2 immunostained sections were photographed at a $\times 1.2$ magnification using a stereomicroscope (Olympus). The total cortical area was measured on the tangential sections. The posteromedial barrel subfield (PMBSF) was outlined with Image software and its area measured. Within this area, the vGlut2-positive regions correspond to the barrel hollows containing the dense TC axon terminals. The vGlut2-positive patches were outlined and their areas measured. The total PMBSF area minus the sum of vGlut2-positive areas was used as an estimate of the total interbarrel area. We refer to this value as the septal area in the rest of the manuscript, although strictly speaking, it comprises two different elements, the cellular wall surrounding the hollows and a septal region between the barrel walls. Interestingly double immunostainings for vGlut 2 and Tenascin, an extracellular glycoprotein that surrounds structural and functional developing barrels in S1 (Crossin et al., 1989; Steindler et al., 1990) showed that tenascin-positive regions corresponded precisely to the vGlut2-negative regions.

Quantification of neuronal density. Photomicrographs of tangential sections immunostained for vGlut 2 and Cux 1 were acquired with a $40 \times$ objective using a Leica SP2 confocal microscope. The C2 barrel was placed in the center of the field and a single confocal section was acquired. The vGlut2-positive area was delimited after automatic thresholding using a fixed threshold value (MetaMorph Software). This area was defined as the barrel hollow. A $20 \mu \mathrm{m}$ thick belt surrounding the barrel hollow was computed using MetaMorph imaging software. This area was defined as the barrel wall (Ballester-Rosado et al., 2010). The Cux1-positive cell nuclei were counted with the cell counter plug-in 
(ImageJ software) within the barrel hollow and the wall compartments. Stereological methods were applied to avoid multiple counting. The cell counts were normalized per surface area for each compartment, providing cell density estimates for the hollow and wall compartments.

Quantification of colocalization. Pictures of coronal sections from P10 Sert ${ }^{\text {Cre/+ }}$ Tau ${ }^{\text {mGFP-ires-LacZ }}$ and Emx $1^{\text {Cre/+ }}$ Tau ${ }^{\text {mGFP-ires-LacZ, immuno- }}$ stained for $\beta$-Gal together with NeuN, were acquired with the confocal microscope. Using the cell counter plug-in of ImageJ, the number of $\beta$-galactosidase-positive neurons within the NeuN population was measured in the $\mathrm{VB}$ and posterior medial (POm) nuclei of the thalamus and in the cerebral cortex layers.

\section{Statistical analysis}

All measures were done blind to genotype. For statistical analysis, the distributions of the results were tested with a Shapiro-Wilk test, followed by an $f$ test. We found a normal distribution in the experiments analyzed. In most cases, the variance between groups was similar and a nondirectional Student's $t$ test was applied. When variance was different, a nondirectional homoscedastic $t$ test was used. To compare small populations $(n<6)$, Mann-Whitney tests were applied.

\section{Electrophysiology}

TC slice preparation. Animals (P5-P7) were anesthetized by intraperitoneal injection of pentobarbital $(15 \mathrm{mg} / \mathrm{kg})$ and decapitated. The brain was quickly removed and placed in ice-cold $\left(2-4^{\circ} \mathrm{C}\right)$ oxygenated $\left(5 \% \mathrm{O}_{2}\right.$, 95\% $\mathrm{CO}_{2}$ ) standard artificial CSF (ACSF). TC slices were cut (thickness, $400 \mu \mathrm{m})$ using a vibratome (VT100S; Leica), as previously described (Laurent et al., 2002). The slices were first maintained $1 \mathrm{~h}$ at $33^{\circ} \mathrm{C}$ and later at room temperature $\left(22-24^{\circ} \mathrm{C}\right)$ in oxygenated standard ACSF.

Electrophysiological recordings. For recordings, the slices were glued on a polylysine-coated small (1.2 $\mathrm{mm}$ diameter) glass coverslip, which was then placed in a small $(\sim 1 \mathrm{ml})$ chamber, perfused at $3 \mathrm{ml} / \mathrm{min}$ with ACSF at near physiological temperature $\left(33-34^{\circ} \mathrm{C}\right)$. Recordings were obtained from layer IV neurons identified under visual control using an upright fixed-stage microscope (Axioskop FS, Zeiss) equipped with infrared Nomarski optics and a video camera (Cascade 512B, Roper Scientific). Somatic whole-cell recordings were performed using borosilicate glass pipettes with a tip resistance of 2-3 M $\Omega$ and an Axopatch 200B amplifier (Molecular Devices). The recorded neurons were maintained in voltageclamp mode using whole-cell patch-clamp techniques. Membrane capacitance and serial resistance were not compensated. Voltage and current signals were filtered at $5 \mathrm{kHz}$, digitized at $100 \mathrm{kHz}$ using a digital board (Digidata 1322A, Molecular Devices), and stored on computer. The protocols were generated using the program pClamp10 (Molecular Devices). The series resistance ( $R \mathrm{~s})$ was estimated using a short-duration $(20 \mathrm{~ms})$ negative voltage step $(3 \mathrm{mV})$ preceding by $200 \mathrm{~ms}$ the electrical stimulation of the afferent fibers. Typical Rs, calculated at the beginning of the current step using Ohm's law, were of the order of 5-20 M $\Omega$, and recordings were discarded when $R$ s changed by $>20 \%$ during recording. Afferent TC fibers were stimulated by applying short-duration $(20 \mu \mathrm{s})$ current steps with an isolated voltage stimulator (DS2A, Digitimer), through bipolar tungsten electrodes (SNEX200x50, Rhodes Medical Instruments) placed on the ascending TC pathway in the internal capsule (IC). As shown previously (Laurent et al., 2002), low-frequency $(0.03 \mathrm{~Hz})$ extracellular IC stimulation evoked stable glutamatergic EPSC in the layer IV spiny stellate neurons. The unitary EPSC due to single afferent fiber stimulation (Laurent et al., 2002) was found by progressively increasing the stimulation intensity until a plateau unitary response was obtained (see Fig. 2a; Takahashi, 1992; Silver et al., 1996). To unambiguously define the single fiber unitary EPSC, we plotted the amplitude of the responses in relation with the stimulation intensity. A shown in our previous work at cortical (Laurent et al., 2002), and thalamic (Evrard and Ropert, 2009) synapses, it is sometimes possible to distinguish axonal failure from release failure. In most cases, there was no evidence for axonal failures and the response changes from complete failures at smaller intensity $(<2.3 \mathrm{~mA}$, Fig. $2 a 2)$, to a stable unitary response at higher intensities. In such cases the stimulation intensity was maintained above threshold.

The data were analyzed offline using Clampex (Molecular Devices), Excel (Microsoft), and Igor Pro 4.1 (WaveMetrics). The amplitude of the
AMPA receptor (AMPAR)-mediated component of the EPSC at -70 $\mathrm{mV}$ was measured between the baseline and the peak of the response by averaging the signal during a short time window $(40 \mu \mathrm{s})$. The amplitude of the NMDAR component of the EPSC was measured at $+30 \mathrm{mV}$ by averaging the current recorded during an identical time window $(40 \mu \mathrm{s})$ placed $15 \mathrm{~ms}$ after the stimulation. The EPSC failure was measured at $-70 \mathrm{mV}$ and was defined as a response that was smaller than twice the SD of the baseline current. The EPSC latency was defined as the time when the EPSC reached $10 \%$ of its peak amplitude. Paired-pulse ratios (PPRs) were obtained by applying two stimulations at various time intervals and calculated at $-70 \mathrm{mV}$ as the second EPSC amplitude divided by the first EPSC amplitude (EPSC2/EPSC1) including failures. The EPSC kinetics was quantified by fitting their decay with a biexponential function $\mathrm{y}_{0}+$ $\mathrm{A}_{\text {fast }} \mathrm{e}^{-1 / \tau}$ fast $+\mathrm{A}_{\text {slow }} \mathrm{e}^{-1 / \tau}$ slow, $\mathrm{A}_{\text {fast }}$ and $\mathrm{A}_{\text {slow }}$ being the amplitude of the fast and slow components respectively, $\tau_{\text {fast }}$ and $\tau_{\text {slow }}$ their time constant, $\mathrm{y}_{0}$ the offset.

Solutions and drugs. All chemicals were purchased from Sigma unless otherwise specified. Standard ACSF contained the following (in mM): $126 \mathrm{NaCl}$, $2.85 \mathrm{KCl}, 1.25 \mathrm{KH}_{2} \mathrm{PO}_{4}, 1.5 \mathrm{MgSO}_{4}, 2 \mathrm{CaCl}_{2}, 26 \mathrm{NaHCO}_{3}, 5 \mathrm{Na}$-pyruvate and 10 glucose. The following compounds were bath applied: D-(-)-2amino-5-phosphonopentanoic acid (D-AP5, $50 \mu \mathrm{M}$; Ascent Scientific), 2,3dioxo-6-nitro-1,2,3,4-tetrahydrobenzo[f]quinoxaline-7-sulfonamide disodium salt (NBQX, $10 \mu \mathrm{M}$; Ascent Scientific), [6-imino-3-(4-methoxyphenyl)-1(6H)-pyridazinebutanoic acid hydrobromide] (gabazine, $10 \mu \mathrm{M}$; Ascent Scientific).

The intracellular pipette solution contained the following (in $\mathrm{mM}$ ): 120 Cs methylsulfonate, $10 \mathrm{CsCl}, 10$ HEPES, $4 \mathrm{~K}-\mathrm{ATP}, 2 \mathrm{MgCl} 2,0.4 \mathrm{Na}-\mathrm{GTP}$, and 0.2 EGTA, pH adjusted to 7.35 using $\mathrm{CsOH}$. All voltage values were corrected for a $-9 \mathrm{mV}$ liquid junction potential.

\section{Pre-embedding immunolabeling electron microscopy}

Adult mice (2 Ctrl and 2 RIM-DKO ${ }^{\text {Sert }}$ ) were anesthetized with sodium pentobarbital and transcardially perfused with $4 \%$ paraformaldehyde + $0.5 \%$ glutaraldehyde in cold $0.1 \mathrm{M}$ phosphate buffer. Brains were further postfixed in $4 \%$ paraformaldehyde $+15 \%$ sucrose for $2 \mathrm{~h}$ at $4^{\circ}$ and then cut in $80 \mu \mathrm{m}$ thick coronal sections with a vibratome. Thorough rinses were followed by a blocking step in 5\% normal goat serum $+5 \%$ BSA and then an overnight incubation at room temperature in guinea-pig polyclonal Ab vGlut2 (1:8000 Millipore Bioscience Research Reagents) diluted in PBS $+2 \%$ Normal Goat Serum.

For immunoperoxidase procedures, a biotinylated anti-guinea pig IgG (Vector, CA) was applied as secondary Ab (1/200 in PBS, $2 \mathrm{~h}$ ), an ABC peroxidase complex (Vectastain Elite) diluted $1 / 400$ was used for amplification and revelation was performed with $0.05 \%$ diaminobenzidine as chromogen.

For immunogold labeling, a $4 \mathrm{~h}$ incubation in ultra-small gold conjugate of goat anti-guinea pig IgG (1/100; Aurion) was followed by extensive washings, 10 min postfixation in $2 \%$ glutaraldehyde, and the $0.7 \mathrm{~nm}$ gold beads were then silver enhanced (HQ silver; Nanoprobes).

After $\mathrm{OsO} 4$ postfixation (2\% for immunoperoxidase labeling, $1 \%$ for silver-gold revelation), sections were dehydrated in graded acetone with a $2 \%$ uranyl acetate en bloc staining step in acetone $70 \%$, and finally embedded in Epon resin. Ultrathin sections were examined with a Philips CM100 electron microscope, operated at $80 \mathrm{kV}$ and imaged with a Gatan digital camera.

To locate vGlut2-positive synapses within layer IV, the borders of the layer were outlined on a micrograph of the Nissl-stained semithin section immediately preceding the ultrathin sections. Boundary lines were then transferred on a low-magnification electron micrograph to identify the zone in which the positive synapses were examined.

\section{Golgi-Cox}

Mice were killed and perfused with $0.9 \% \mathrm{NaCl}$. Brains were dissected and soaked in the Golgi-Cox filtrated solution $\left(\mathrm{K}_{2} \mathrm{Cr}_{2} \mathrm{O}_{7} 35 \mathrm{~mm}, \mathrm{~K}_{2} \mathrm{CrO}_{4} 43\right.$ $\mathrm{mM}, \mathrm{HgCl}_{2} 38 \mathrm{~mm}$ ) for $2 \mathrm{~d}$, rinsed in $30 \%$ sucrose for 1 week and sectioned at $200 \mu \mathrm{m}$ with a vibratome (Leica VT1000). Sections were mounted on slides, color reacted in $30 \% \mathrm{NH}_{4} \mathrm{OH}$ for $30 \mathrm{~min}$, and fixed in $30 \%$ AL4 Kodak photo fixative for $30 \mathrm{~min}$. They were counterstained with cresyl violet, dehydrated and coverslipped with Eukitt (Electron 
Microscopy Sciences). Neurons were drawn using a camera lucida with a $100 \times$ oil-immersion objective for dendritic analyses. A total of $50 \mathrm{Ctrl}$ and 41 RIM-DKO ${ }^{\text {Sert }}$ layer IV spiny stellate cells were reconstructed from 4 mice of each genotype. Morphometric analysis of dendrites was done with NeuronJ software. Asymmetry of dendrites was measured as described previously (Datwani et al., 2002), briefly, a line was drawn between the tip of each dendrite and the center of the soma. Neurons were considered as asymmetric when $50 \%$ or more of these lines representing dendrites were oriented in a $90^{\circ}$ angle. Otherwise, they were counted as symmetric. The proportions between genotypes were tested with a $\chi^{2}$ test. A two dimensional Sholl analysis (Sholl, 1953) was used to analyze dendritic branching patterns. Concentric circles of $10 \mu \mathrm{m}$ intervals were brought over each cell with the center of the circles positioned in the middle of the soma. Intersections of different dendritic orders and circles were counted.

The cell count plug-in of the ImageJ program was used to count the number of branches and bifurcation points. The same program was used to count spines on $20 \mu \mathrm{m}$ portions of the secondary and tertiary dendrites from stacks of photomicrographs captured using a $100 \times$ oil objective on a Leica microscope. Statistical comparisons used ANOVA.

\section{Voltage-sensitive dye imaging}

Voltage-sensitive dye (VSD) imaging of the cortical activity evoked by tactile stimulation was performed on 6- to 8-week-old mice under urethane anesthesia $(1.7 \mathrm{mg} / \mathrm{g})$, as previously described (Ferezou et al., 2007). Briefly, a large fraction of mouse sensorimotor cortex was exposed unilaterally and stained for $1 \mathrm{~h}$ with the VSD RH1691 (Optical imaging, $1 \mathrm{mg} / \mathrm{ml}$, in Ringer's solution containing [in mM]: 135 $\mathrm{NaCl}, 5 \mathrm{KCl}, 5 \mathrm{HEPES}, 1.8 \mathrm{CaCl} 2,1 \mathrm{MgCl} 2)$. After removing the unbound dye, the cortex was covered with agarose $(0.5 \%)$ and a coverslip. Cortical imaging was done through a tandem-lens fluorescence microscope (Scimedia), equipped with 2 Leica PlanApo $1 \times$ objectives, a $630 \mathrm{~nm}$ excitation filter, a $650 \mathrm{~nm}$ dichroic, and a long pass $665 \mathrm{~nm}$ emission filter. Alternate sequences of images were acquired every $20 \mathrm{~s}$ (at $500 \mathrm{frames} / \mathrm{s}$ ), using a CMOS-based camera (MiCam Ultima, SciMedia), with or without piezzo electric stimulus (2 ms) delivered to the right C2 whisker. Data were analyzed using custom-written routines in IgorPro (Wavemetrics). Subtraction of the averaged unstimulated sequences was used to correct for photobleaching.

\section{Sensory-mediated c-Fos expression}

All whiskers of adult mice were clipped on the right side, under light anesthesia (ketamine, $100 \mathrm{mg} / \mathrm{kg} \mathrm{IP}$ ). The following day, mice were placed in a cage containing new objects (typically a cardboard tube, two plastic goblets and two balls of paper for each cage). Mice explored this new environment for $1 \mathrm{~h}$, after which they were perfused. For c-Fos immunostaining, brains were sectioned at $50 \mu \mathrm{m}$ with a vibratome (Leica VT1000). Immunohistochemistry was performed as described above.

\section{Object exploration}

Training and testing were conducted in Plexiglas boxes (white floor, gray walls) of $17 \times 32 \times 40 \mathrm{~cm}$, in the dark. Before the test, animals were habituated to the empty boxes in $10 \mathrm{~min}$ sessions for two consecutive days. For the test, two objects were placed in the boxes and animals were allowed to freely explore for $10 \mathrm{~min}$. Sessions were recorded and analyzed using Viewpoint software. The software determined both the position of the nose and the center of mass of the mouse. Center of mass position over time determined the speed of the mouse during exploration, and object exploration was defined when the nose was within a $2 \mathrm{~cm}$ large circle around the object. Eight control and 9 RIM-DKO ${ }^{\text {Sert }}$ mice were used for this test.

\section{Beam walking test}

The test was conducted as described previously (Carter et al., 2001). Briefly, mice were trained for $4 \mathrm{~d}$ to walk on an elevated $22 \mathrm{~mm}$ section beam to reach a platform. On the trial day, each mouse was given three trials to cross the beam and the time used to do so was noted. When mice did not succeed to reach the platform within $2 \mathrm{~min}$, the trial was considered as a failure. The two best times over the three trials were averaged to determine each mouse's crossing time. All failures per genotype were summed and averaged to estimate the probability of failure per trial. Seven Ctrl and 9 RIM-DKO ${ }^{\text {Sert }}$ mice were used for this test.

\section{Results \\ Region-specific deletion of RIM genes in the thalamus or cortex}

The presence of RIM $1 \alpha$ and RIM $1 \beta$ has been reported as early as P1 in brain extracts (Kaeser et al., 2008). To determine the cellular localization of RIM1 and RIM2 expression along the thalamocortical pathway, we performed in situ hybridization (ISH) analyses from P1 to P14 using full-length probes that recognize either all RIM1 or all RIM2 splice variants. During the first postnatal week, RIM1 was broadly expressed in the forebrain with a stronger expression in the cerebral cortex and weaker expression in the thalamus (Fig. $1 a-d$ ). RIM2 was expressed in partly overlapping domains in the thalamus and in the cerebral cortex (Fig. $1 e-h)$.

Cre-mediated recombination of the RIM1 and RIM2 floxed alleles removes all isoforms expressed from these genes (RIM1 $\alpha$, $1 \beta, 2 \alpha, 2 \beta$, and $2 \gamma$; Kaeser et al., 2008, 2011), in contrast to the constitutive $\alpha$-RIM KOs (Schoch et al., 2001, 2006). To optimize the recombination of the RIM1 and RIM2 genes, heterozygous RIM1/RIM2 floxed/null mice were used.

To ablate RIMs in the thalamus, the RIM1/RIM2 floxed mice were crossed to a mouse line expressing Cre recombinase in the serotonin transporter (Sert, Sl6a4) gene, generating RIM$\mathrm{DKO}^{\text {Sert }}$ mice. Sert is strongly expressed in the major thalamic sensory relay nuclei during development (Lebrand et al., 1998), and Cre expression driven by the Sert promoter is efficient in the thalamus, occurring by embryonic day 15 (E15) (Narboux-Nême et al., 2008). Because Cre is inserted into the Sert locus, care was taken to maintain only one Cre allele. To evaluate the percentage of recombination in the different somatosensory relays, we crossed Sert-Cre mice with the Tau ${ }^{\text {mgfp-nls-lacZ }}$ reporter strain (Hippenmeyer et al., 2005). After recombination, neurons express a nuclear $\beta$-galactosidase (Fig. $1 i, j$ ). X-gal staining revealed that the somatosensory thalamus relay shows high levels of recombination: in the VB nucleus, which receives lemniscal inputs and projects to cortical layers IV and VI, $96 \%$ of the NeuNpositive neurons expressed $\beta$-galactosidase at P10 $(n=2,1200$ neurons, Fig. 1j). In the POm, which receives paralemniscal inputs and projects to the septae in layer IV and to layers Va and I, $89 \%$ of the NeuN-positive neurons expressed $\beta$-galactosidase (Fig. $1 k, n=2$ mice, 540 neurons). No recombination was noted in the brainstem trigeminal nuclei. In the cerebral cortex, some recombination was noted in the deep layers: $3.25 \%$ of layer VI neurons expressed $\beta$-galactosidase ( $n=3$ mice, 1050 neurons). While no recombination was observed in layers I-V.

To quantify the recombination of the RIM genes in the RIM$\mathrm{DKO}^{\text {Sert }}$ mice, we performed qPCR on thalamic and cortical extracts from P7 RIM-DKO ${ }^{\text {Sert }}$ brains. There was a strong reduction of both RIM1 and RIM2 in the thalamus compared with control [RIM1: $12 \%( \pm 1.2 \%)$ of control, $n=3-5$ mice, $p=$ 0.018; RIM2: $5 \%$ ( $\pm 1.3 \%$ ) of control, $n=3-5$ mice, $p=0.012$ ], and no difference was found in the cerebral cortex [RIM1: 101\% ( $\pm 38 \%)$ of control, $n=3-4$ mice, $p=0.314$; RIM2: $94 \%$ $( \pm 27 \%)$ of control, $n=3-4$ mice, $p=0.5$; Fig. $1 k]$.

To ablate RIM proteins in developing cortical neurons, we used the Emx1-Cre mouse in which recombination was found to occur in all excitatory cortical neurons derived from the cortical plate by E10.5 (Iwasato et al., 2000). Mice derived from Emx1Cre $\times$ Tau ${ }^{\text {mgfp-nls-lacZ }}$ crossings confirmed the strong recombina- 


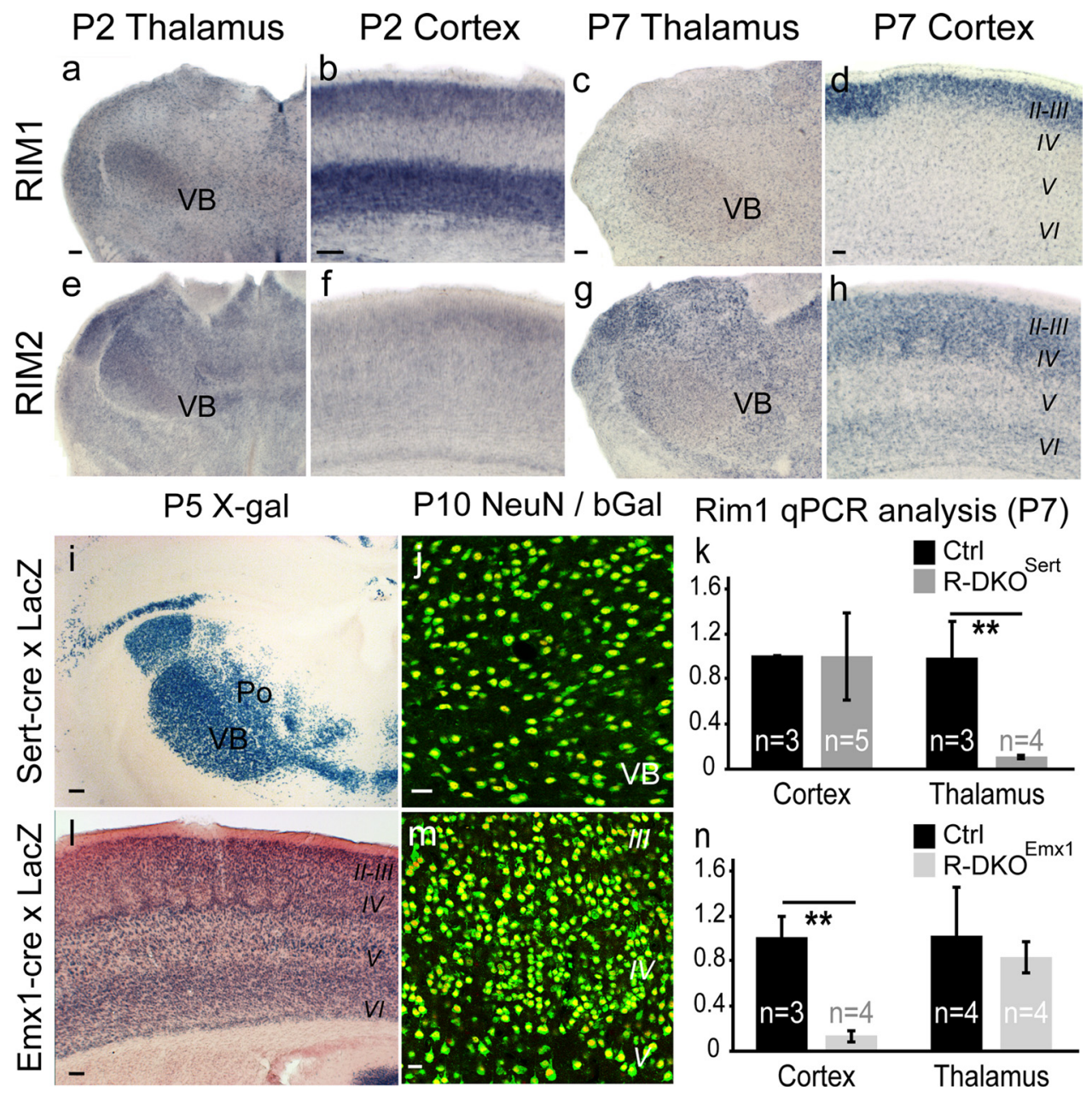

Figure 1. RIM 1 and RIM2 expression and Cre-mediated recombination. $\boldsymbol{a}-\boldsymbol{h}$, In situ hybridization using RIM1 and RIM2 antisense probes at P2 and P7. $\boldsymbol{a}-\boldsymbol{d}$, RIM1 is expressed in the somatosensory thalamus (VB; $\boldsymbol{a})$ and in the cortex with highest expression in deep layers at P2 $(\boldsymbol{b})$ and upper layers at P7 (d). $\boldsymbol{e}-\boldsymbol{h}, \mathrm{RIM} 2$ is broadly expressed in the thalamus including the VB (e), with a low expression in the P2 cerebral cortex $(\boldsymbol{f})$ and higher expression at P7 $(\boldsymbol{h}) . \boldsymbol{i}-\boldsymbol{n}$, Recombination induced by Sert-cre and Emx1-cre. Cre mice were crossed with a reporter strain expressing

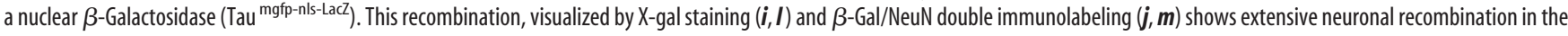
VB of Sert-cre mice $(\boldsymbol{i}, \boldsymbol{j})$, and cerebral cortex of Emx1-cre mice $(\boldsymbol{I}, \boldsymbol{m}) . \boldsymbol{k}, \boldsymbol{n}$, Thalamic and cortical mRNAs from P7 brains of both strains were extracted and measured by qPCR. Results for Rim1 are summarized in $\boldsymbol{k}$ for RIM-DKO ${ }^{\text {Sert }}$ and in $\boldsymbol{n}$ for RIM-DKO ${ }^{\mathrm{Em} \times 1} .^{* *} p<0.05$. Scale bars: (in $\boldsymbol{a}-\boldsymbol{i}, \boldsymbol{I}, 100 \mu \mathrm{m} ; \boldsymbol{j}, \boldsymbol{m}, 25 \mu \mathrm{m}$.

tion in the cerebral cortex (Fig. 1l), showing also scattered recombination in the thalamus. Quantifications of the proportion of neurons recombined by $\beta$-Gal/NeuN colocalization on confocal images revealed that $87.3 \%$ of cortical neurons express $\beta$-Gal ( $n=3$ mice, 1575 neurons), which corresponds approximately to the entire population of glutamatergic neurons in the cortex, while in the VB somatosensory thalamus, $22 \%$ of the neurons expressed $\beta$ - $\mathrm{Gal}$ ( $n=3,3150$ neurons).

RIM-DKO ${ }^{\mathrm{emxl}}$ mice, $\mathrm{qPCR}$ showed a strong reduction of both RIM1 and RIM2 in the cortex compared with control (RIM1: $14 \%$ ( $\pm 5 \%$ ) of control, $n=3-4$ mice, $p=0.029$; RIM2: $17 \%( \pm 3 \%)$ of control $n=3-4$, mice $p=0.03$ ), and small non-significant reduction of RIMs in the thalamus (RIM1: 83\% ( $\pm 14 \%)$ of control, $n=4$ mice, $p=0.5$; RIM2: $81 \%( \pm 21 \%)$ of control, $n=4$ mice, $p=0.35$; Fig. $1 n$ ).

Deletion of RIMs in the thalamus impairs glutamate release at the TC synapse

Previous findings showed that the ablation of RIM proteins causes a massive decrease in evoked EPSC and IPSC amplitudes. The frequency of miniature EPSC and IPSC (mEPSC and mIPSC) was also reduced without changing their amplitude. The reduction of synaptic transmission was associated with a reduction of the readily releasable pool (RRP) and of the voltage-gated $\mathrm{Ca}^{2+}$ current due to a deficit in the coupling between $\mathrm{Ca}^{2+}$ channels and the RRP (Deng et al., 2011; Han et al., 2011; Kaeser et al., 2011). To test the functional properties of TC synapses in the barrel cortex, experiments were conducted in P5 to P7 control and RIM-DKO ${ }^{\text {sert }}$ mice from the same litters using acute TC slices (Fig. 2).

The AMPA component of the TC monosynaptic EPSC was recorded at $-70 \mathrm{mV}$ in the presence of gabazine $(10 \mu \mathrm{M})$, and D-AP5 $(50 \mu \mathrm{M})$, which are $\mathrm{GABA}_{\mathrm{A}}$ and NMDA receptor antagonists, respectively. In control animals, low-frequency $(0.03 \mathrm{~Hz})$ minimal electrical stimulation of the internal capsule (IC) evoked a stable single fiber unitary EPSC in layer IV spiny stellate neurons (Fig. 2a1,a2) with a small failure rate as previously described (Laurent et al., 2002). In RIM-DKO ${ }^{\text {Sert }}$ littermates, EPSCs were also observed at the same latency $(4.9 \pm 0.2 \mathrm{~ms}, n=9$, in control; $4.8 \pm 0.1 \mathrm{~ms}, n=11$, in the RIM-DKO $\left.{ }^{\text {Sert }}\right)$. However the efficacy of the TC synaptic transmission, measured as the average amplitude of the unitary responses including failures, appeared much weaker in RIM-DKO ${ }^{\text {Sert }}$ than in control mice $(34.9 \pm 4.4 \mathrm{pA}, n=$ 9 , in control; $11.6 \pm 2.6 \mathrm{pA}, n=11$, in RIM-DKO ${ }^{\text {Sert }} ; p<0.0001$; 

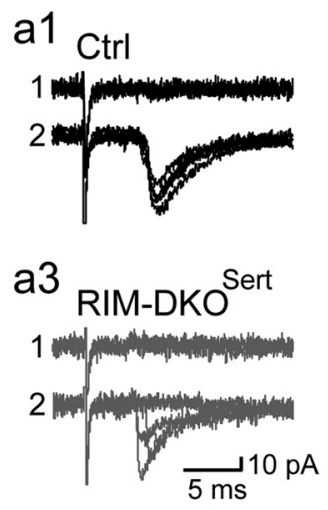

a2

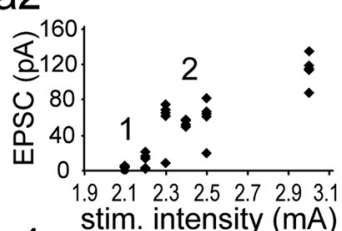

a4

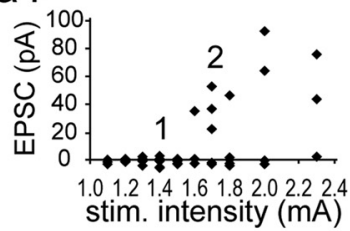

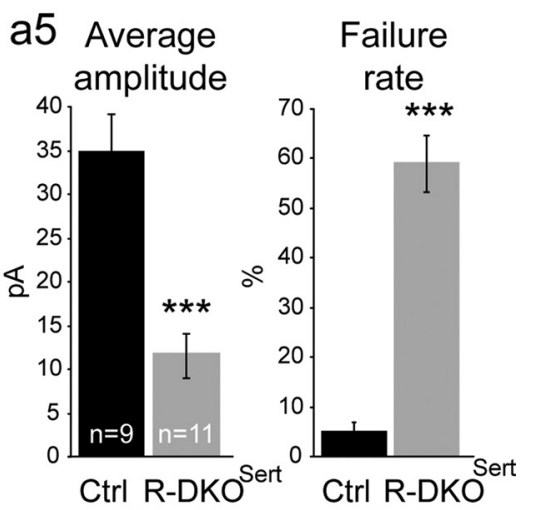
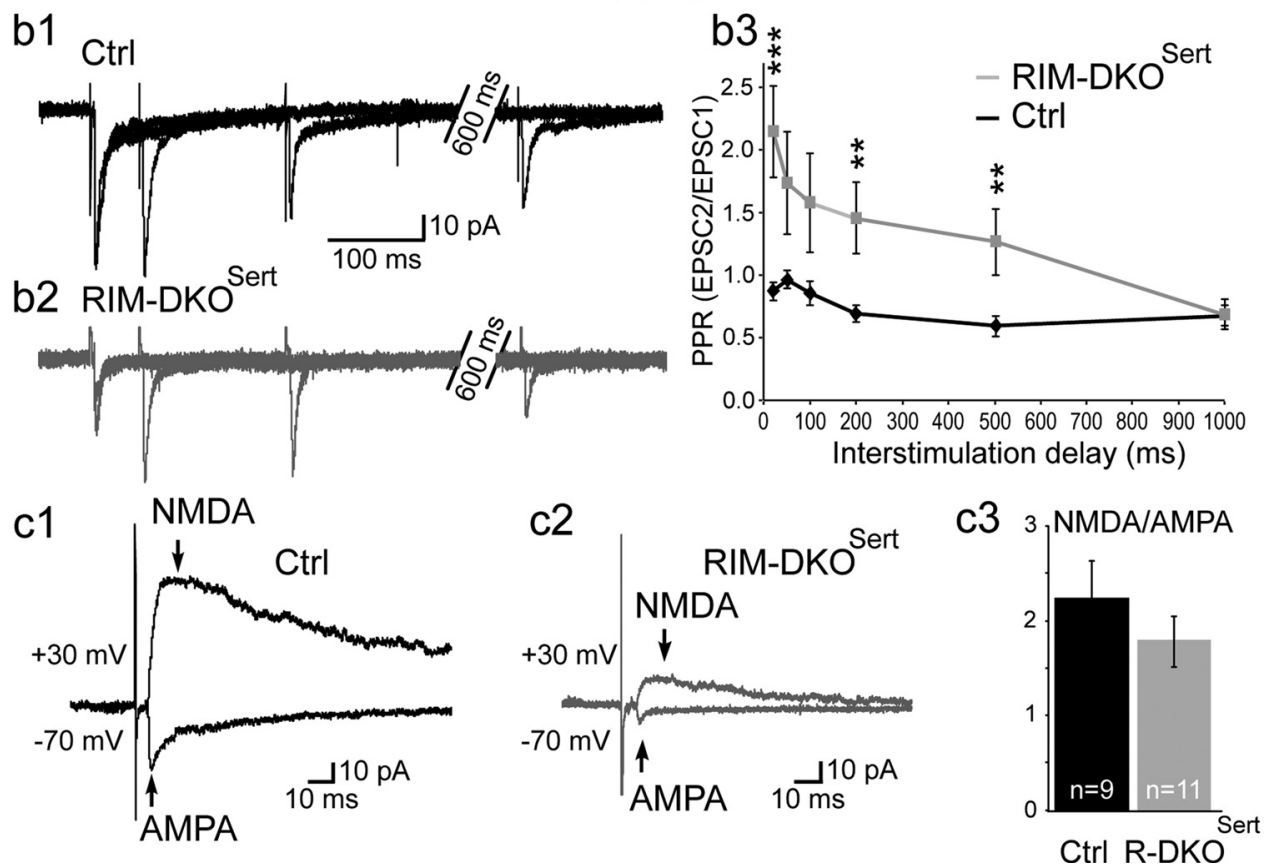

Figure 2. Reduction of the TC synaptic transmission in the RIM-DKO Sert mice. The TC synapses were analyzed in P5 to P7 brain slices preserving the TC pathway. TC axons were stimulated at low frequency $(0.03 \mathrm{~Hz})$ in the internal capsule and the TC EPSCs were recorded in layer IV neurons. $\boldsymbol{a 1}, \boldsymbol{a}$ 3, Superimposed individual responses show failures (1) and single afferent fiber EPSC (2) in control (a1) and RIM-DKO ${ }^{\text {Sert }}$ (a) mice. $\mathbf{a 2}, \mathbf{a 4}$, The peak amplitude of the AMPA component of the evoked TC EPSC is plotted against the IC stimulation intensity for the same recordings in control (a2) and RIM-DKO ${ }^{\text {Sert }}$ (a4) mice. This curve was plotted for every recording to find out the stimulation intensity needed to record a single afferent fiber unitary EPSC, that is $2.4 \mathrm{~mA}$ in control and $1.7 \mathrm{~mA}$ in RIM-DKO ${ }^{\text {Sert }}$ mice. a5, Summary data (mean \pm SEM) showing a 60\% reduction of the evoked TC unitary EPSC amplitude in the RIM-DKO $0^{\text {Sert }}(n=11$; gray) compared with control ( $n=9$; black) mice. The amplitude of the unitary EPSC includes the failures. The reduction of the unitary EPSC is associated with an increase of the failure rate (*** $p<0.001) . \boldsymbol{b} 1, \boldsymbol{b 2}$, Paired-pulse stimulation experiments at various intervals $(0.05 \mathrm{~s}, 0.2 \mathrm{~s}, 1 \mathrm{~s})$ showed paired pulse depression of the TC EPSCs in control $(\boldsymbol{b} \mathbf{1})$ and paired pulse facilitation in RIM-DKO ${ }^{\text {Sert }}$ (b2) mice. $\boldsymbol{b} 3$, Summary data of the paired-pulse ratio at various intervals ( $0.05 \mathrm{~s}, 0.1 \mathrm{~s}, 0.2 \mathrm{~s}, 0.5 \mathrm{~s}, 1 \mathrm{~s})$ in control $\left(n=9\right.$, black curve) and RIM-DKO ${ }^{\text {Sert }}(n=11$, gray curve) mice. $c 1, c 2$, The amplitude of the AMPA and NMDA components of the TC EPSC were obtained by recording EPSC at $-70 \mathrm{mV}$ and $+30 \mathrm{mV}$ in control (c1) and RIM-DKO ${ }^{\text {Sert }}$ (c2) mice. c3, This NMDA/AMPA ratio was found similar in control (2.22 \pm $0.37, n=9)$ and RIM-DKO ${ }^{\text {Sert }}(1.77 \pm 0.27, n=11)$ mice.

Fig. 2). This change of synaptic transmission efficacy correlated with an increased failure rate $(4.8 \pm 2.0 \%$, range $0-16, n=9$ in control; $58.9 \pm 5.8 \%$, range $26-81, n=11$, in RIM-DKO ${ }^{\text {Sert }}$ mice; $p<0.0001$ ). Based on previous evidence of unchanged mEPSC amplitude in the RIM-DKO ${ }^{\text {Sert }}$ mice (Deng et al., 2011; Han et al., 2011), the failure rate increase seen in the RIM$\mathrm{DKO}^{\text {Sert }}$ mice should give an average EPSC amplitude of $15.1 \mathrm{pA}$, a theoretical value close to the experimental value (11.6 pA), suggesting that the reduction of synaptic efficacy at the TC synapse of the RIM-DKO ${ }^{\text {Sert }}$ mice is mostly due to a presynaptic effect on the glutamate release probability. Consistent with a presynaptic modification of the TC transmission, we also observed an increased coefficient of variation $(0.40 \pm 0.04, n=9$ in control; $1.33 \pm 0.013, n=11$ in RIM-DKO ${ }^{\text {Sert }}$ mice), and a change of the paired pulse ratio (PPR) which was estimated by using paired
IC stimulation at several intervals between $20 \mathrm{~ms}$ and $1 \mathrm{~s}$ (Fig. $2 b 1, b 2)$. At $20 \mathrm{~ms}$, the PPR calculated as the ratio between the second and first EPSC amplitude (EPSC2/EPSC1) was significantly increased in the RIM-DKO ${ }^{\text {Sert }}(0.87 \pm 0.08, n=8$ in control; $2.15 \pm 0.37, n=9$ in the RIM-DKO ${ }^{\text {Sert }}$ mice; $p<0.01$; Fig. 2b3).

To test whether the expression of the postsynaptic ionotropic glutamatergic receptors by the layer IV neurons was affected in RIM-DKO ${ }^{\text {Sert }}$ mice, single fiber IC stimulations were used in presence of gabazine $(10 \mu \mathrm{M})$. The NMDA/AMPA ratio, measured at the peak of the NMDA component of the EPSCs at +30 $\mathrm{mV}$ and the AMPA component at $-70 \mathrm{mV}$ (Fig. 2c1,c2). This ratio was similar in controls $(2.22 \pm 0.37, n=9)$ and RIM$\mathrm{DKO}^{\text {Sert }}$ mice $(1.77 \pm 0.27, n=11$; Fig. $2 c 3)$, indicating that the relative proportion of postsynaptic AMPA and NMDA receptors 

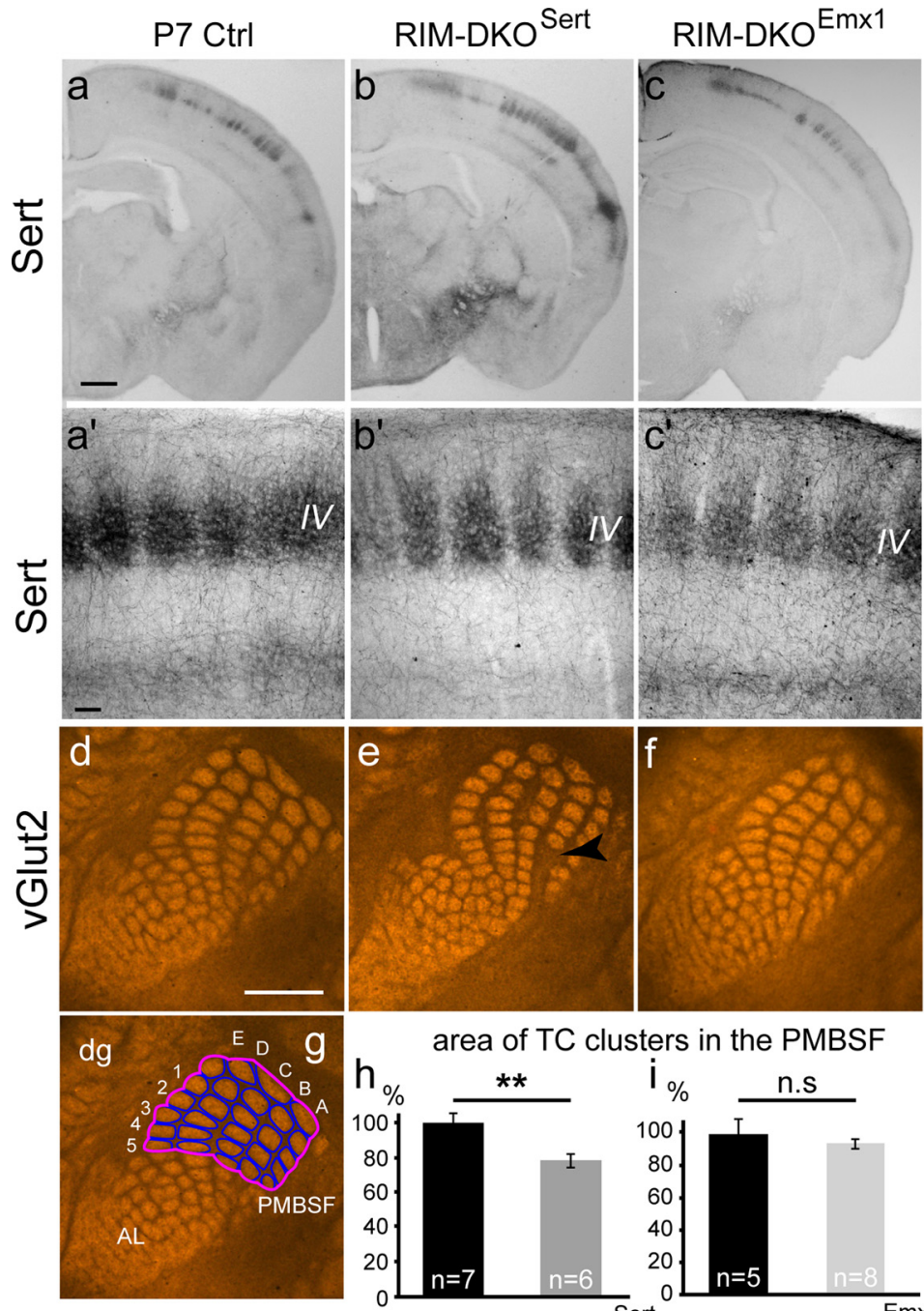

area of TC clusters in the PMBSF
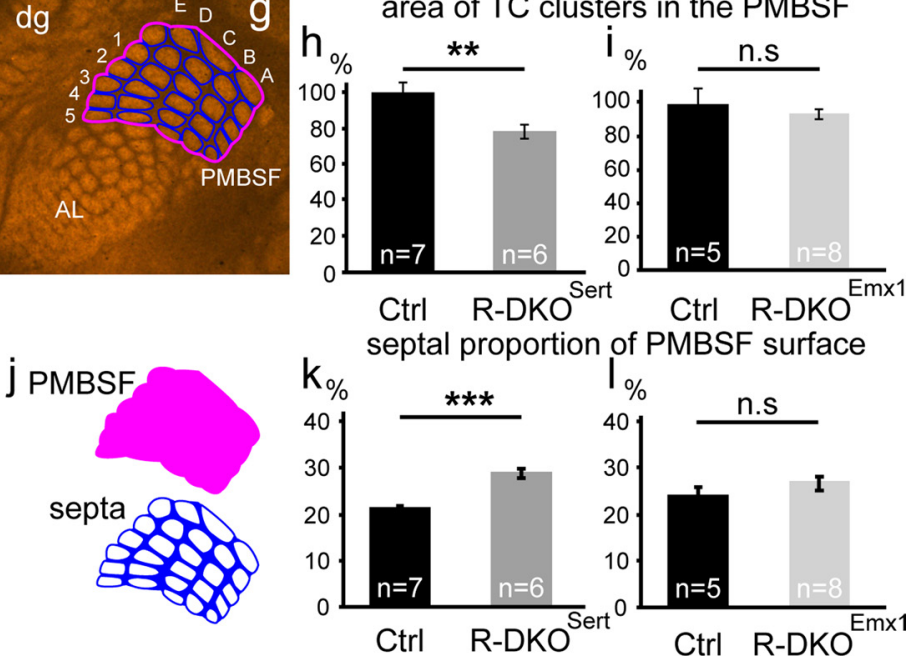

Figure 3. Laminar and tangential distribution of TC axons in S1 of RIM-DKO ${ }^{\text {Sert }}$ and RIM-DKO ${ }^{\text {Emx1 }}$ mice. $\boldsymbol{a}-\boldsymbol{c}$, To analyze the TC tracts and laminar distribution of TC axons in RIM-DKO ${ }^{\text {Sert }}$ and RIM-DKO ${ }^{\text {Emx } 1}$ mice, SERT-immunocytochemistry was performed in coronal sections of P7 brains. In the three genotypes: control $(\boldsymbol{a})$, RIM-DKO ${ }^{\text {Sert }}(\boldsymbol{b})$, and RIM-DKO ${ }^{\text {Emx1 }}$ (c), thalamic axons reach the cortical layers VI and IV where they arborize into well delimited clusters $\left(\boldsymbol{a}^{\prime}-\boldsymbol{c}^{\prime}\right) \cdot \boldsymbol{d}-\boldsymbol{f}$, To evaluate the topographic map formed by TC axons in a tangential plane, vGlut2 immunohistochemistry was performed on serial tangential sections of flattened cortical hemispheres of P7 mice. The sections through layer IV were photographed and analyzed. The TC clusters corresponding to the barrels of the principal whiskers in the PMBSF are clearly delimited in control (d) RIM-DKO ${ }^{\text {Sert }}(\boldsymbol{e})$ and RIM-DKO ${ }^{\mathrm{Em} \times 1}(\boldsymbol{f})$ mice; Increase in the septal intervals between barrel rows in the RIM-DKO ${ }^{\text {Sert }}$ cortex is shown with arrowhead in $\boldsymbol{e} . \boldsymbol{g}, \boldsymbol{j}$, quantification method: the PMBSF area was delimited by joining the external boundaries of the vGlut2 stained patches corresponding to the five rows of the main vibrissae (delineated in pink). The area covered by the individual TC patches/barrels was measured (white areas) and the septal area was calculated as the difference between these two areas (blue area). $\boldsymbol{h}, \boldsymbol{i}$, histograms showing the summed area of each individual patch in the PMBSF, normalized to area measured in the control, in the RIM-DKO ${ }^{\text {Sert }}(\boldsymbol{h})$ and the RIM-DKO ${ }^{\mathrm{Em} \times 1}(\boldsymbol{i})$ mice; $\boldsymbol{k}, \boldsymbol{l}$, quantification of the septal/PMBSF area ratio in RIM-DKO ${ }^{\text {Sert }}(\boldsymbol{k})$ and RIM-DKO ${ }^{\mathrm{Em \times 1}}(\boldsymbol{I})$ mice. AL: anterolateral barrel subfield, $d g$ : digits; PMBSF: posteromedial barrel subfields, A-E: barrel rows, 1-5: barrel columns. Scale bars: $\boldsymbol{a}, 500 \mu \mathrm{m} ; \boldsymbol{a}^{\prime}, 100 \mu \mathrm{m}$; d, $1 \mathrm{~mm}$. is unchanged when presynaptic RIMs are lacking. The fast AMPA receptormediated EPSC recorded at $-70 \mathrm{mV}$ was followed by a slower component with variable amplitude, likely due to the activation of kainate receptors following glutamate release at the TC synapse (Kidd and Isaac, 1999). We found no significant difference in the relative amplitude and kinetics of the two components of the EPSC in control and RIM-DKO ${ }^{\text {Sert }}$ mice $\left(\mathrm{A}_{\text {fast }} / \mathrm{A}_{\text {fast }}+\mathrm{A}_{\text {slow }}\right.$ being $0.86 \pm 0.03$ and $0.90 \pm 0.02, p=0.33$, in control and RIM$\mathrm{DKO}^{\text {Sert }}$ mice, respectively; $\tau_{\text {fast }}$ being $3.10 \pm 0.4 \mathrm{~ms}$ and $2.35 \pm 0.42, p=0.21$, in control and RIM-DKO ${ }^{\text {Sert }}$ mice, respectively; $\tau_{\text {slow }}$ being $91.36 \pm 10.11$ and $175.14 \pm 135.61, p=0.78$ in control and RIM-DKO ${ }^{\text {Sert }}$ mice, respectively). Together these results indicate that the expression of ionotropic glutamate receptors is unchanged in layer IV spiny stellate cells of the RIM-DKO ${ }^{\text {Sert }}$ mice.

Overall, these experiments indicate that the combination of RIM1 and RIM2 KOs at the TC synapses reduces the efficacy and reliability of the TC transmission without affecting the expression of ionotropic glutamate receptors in layer IV spiny stellate cells.

\section{Deletion of RIM genes in the thalamus} or cortex does not affect the somatosensory topographic map made by incoming TC axons

The development of a normal architecture of the barrel cortex comprises two coordinated events: first, the formation of periphery-related patterns by the sensory TC afferents, and second, the clustering of layer IV neurons. The emergence of TC periphery-related patterns begins by $\mathrm{P} 3$ in mice. Patterning is first noted in PMBSF that corresponds to the large whiskers, and then by $\mathrm{P} 5$ in the anterior lateral barrel subfield (ALBSF) that corresponds to the sinus hair representations (Senft and Woolsey, 1991; Rebsam et al., 2002).

We analyzed the general topography and laminar distribution of the developing TC axons by Sert immunohistochemistry which labels the TC axons as a population at P7 (Lebrand et al., 1998). We found that the laminar position of the TC axonal clusters in cortical layers IV and VI was unchanged in RIM-DKO $^{\text {Sert }}(n=6)$ and RIM-DKO ${ }^{\text {Emxl }}$ $(n=6)$ compared with control $(n=12)$ mice (Fig. $3 a-c^{\prime}$ ).

To analyze the segregation of TC afferents into whisker-related patterns, vGlut2 immunostaining was performed on tangential sections from flattened P7 hemispheres in the RIM-DKO ${ }^{\text {Sert }}$ and the 
RIM-DKO ${ }^{\text {Emxl }}$ mice (Fig. $3 d-f$ ). In all genotypes, clusters of TC terminals corresponding to the different body parts were observed. Both the principal whiskerrelated patterns of the PMBSF and the barrels corresponding to digits and the smaller TC axonal clusters of the ALBSF were sharply outlined (Fig. $3 d-g$ ). However, in the PMBSF of the RIM-DKO ${ }^{\text {Sert }}$ mice, TC clusters appeared smaller with larger interbarrel space (called septae for convenience see Materials and Methods, Measures and cell counts; compare Fig. $3 d, e)$. We measured the area of each TC cluster in the PMBSF as the dense patch of vGlut2-immunostaining (Fig. $3 g$ ). In the RIM-DKO ${ }^{\text {Sert }}$ samples, the summed area of individual barrels was reduced by $22 \% \mathrm{com}$ pared with controls (Fig. 3h; $p=0.0077$ ). To measure the septal area, we outlined the contours of the PMBSF and subtracted the area covered by the TC patches (Fig. 3j). The septal area was increased in the RIM-DKO ${ }^{\text {Sert }}$ samples (Ctrl: $21 \pm 0.6 \%$ RIMDKO $^{\text {Sert }}: 29 \pm 1 \%$ of the total PMBSF area, $p<0.001$; Fig. $3 k$ ). Similar measures in RIM-DKO ${ }^{\mathrm{Emxl}}$ mice showed no change in the size of TC patches (Fig. 3i), or the size of the PMBSF, the area occupied by the TC terminals (RIM-DKO ${ }^{\mathrm{Emx1}}: 93 \pm 3 \%$ of control, $p=0.54$, Fig. $3 i$ ), or the septal regions (Ctrl: $24 \pm 2 \%$; RIM$\mathrm{DKO}^{\text {Emx1 }}: 27 \pm 1 \% ; p=0.29$; Fig. $\left.3 l\right)$.

We further examined the maturation of TC synapses at the ultrastructural level. Because TC synapses represent only $10 \%$ of the total complement of asymmetric synapses in layer IV in the somatosensory cortex (Benshalom and White, 1986), antivGlut2 immunolabeling was used for their specific identification (Nahmani and Erisir, 2005). In 2 months old mice, TC vGlut2labeled terminal butons in layer IV were large, filled with round synaptic vesicles, and faced perforated postsynaptic densities in both control and RIM-DKO ${ }^{\text {Sert }}$ (Fig. 4).

These results indicate that RIM function in either the thalamus or the cortex was not required for the formation by afferent TC axons of a somatosensory map with precise ordering of periphery related patterns. Lack of RIMs in thalamic neurons caused a reduction in the size of TC terminal clusters in layer IV of the barrel cortex, but no change in synapse formation and ultrastructure.

\section{Deletion of RIM genes in the thalamus but not in the cortex causes a barrelless phenotype}

Shortly after the arrival of TC axons in layer IV, spiny stellate neurons adopt a ring-like distribution around each TC axonal cluster (Rice and Van der Loos, 1977), becoming more densely packed on the external boundary of the clusters. We evaluated the organization and density of layer IV neurons with regard to the TC axonal clusters using the nuclear stains DAPI or Cux1 immunostaining that labels a vast majority of glutamatergic layer IV neurons (Nieto et al., 2004; Ferrere et al., 2006). In mice, where only RIM1, or only RIM2 isoforms were invalidated in the thalamus, the neurons in cortical layer IV formed normal ring-like arrangements around the TC clusters, including the smaller barrels corresponding to the sinus hair representations (Fig. $5 a-c^{\prime}$ ). However, when both RIM1 and RIM2 were deleted from the thalamus, cortical neurons showed an even distribution in the barrel walls and center (Fig. $5 d, d^{\prime}, f$ ). To quantify these changes, the density of Cux1-positive neurons was measured in the C2 barrel (Fig. $5 e-h$ ). Neuronal density in the hollow was similar in control and recombined mice (Ctrl: $4873 \pm 429$ neurons $/ \mathrm{mm}^{2 \text {; }}$ RIM-DKO ${ }^{\text {Sert }}: 4777 \pm 282$ neurons $/ \mathrm{mm}^{2}$ ), but was reduced in the barrel wall (Ctrl: $6815 \pm 387$ neurons $/ \mathrm{mm}^{2 ;}$ RIM-DKO ${ }^{\text {Sert }}$ : $5267 \pm 278$ neurons $/ \mathrm{mm}^{2}$. The wall/hollow cell density ratio was greatly reduced in the RIM-DKO ${ }^{\text {Sert }}$ mice (Fig. $5 i$; Ctrl: $1.42 \pm 0.06 n=6$; RIM-DKO ${ }^{\text {Sert }}: 1.1 \pm 0.03, n=8 ; p=0.001$ ). Thus, there is a barrelless phenotype in the RIM-DKO ${ }^{\text {Sert }}$ mice.

Quantification in RIM-DKO ${ }^{\mathrm{Emx} 1}$ mice (Fig. $5 g, j$ ) showed no change in the clustering of the layer IV neurons (wall/hollow cell density ratio: Ctrl: $1.32 \pm 0.05(n=6) ; \mathrm{DKO}^{\mathrm{Emxl}}: 1.35 \pm 0.03$ $(n=6) ; p=0.58)$. In both RIM-DKO ${ }^{\text {Sert }}$ and RIM-DKO ${ }^{\text {Emx1 }}$ mouse strains, barreloids were clearly visible in the thalamus by $\mathrm{CO}$ reaction (data not shown). The alterations in the organization of layer IV neurons in RIM-DKO ${ }^{\text {Sert }}$ mice persisted throughout adult life, as observed with Nissl staining or by the uniform distribution of $\operatorname{ROR} \beta$, a layer IV neuronal marker which expression level was not modified (data not shown).

These results indicated that RIM function is required in the thalamus but not in the cerebral cortex for the development of barrels in the somatosensory cortex. RIM function in this process appears to require both the RIM1 and the RIM 2 genes, as deletion of either of these genes in the thalamus was insufficient to cause barrel formation defects.

\section{Modified dendrite organization in the RIM-DKO ${ }^{\text {Sert }}$ mice}

The formation of barrels involves a reorganization of the dendrites of layer IV neurons that become polarized toward the center of the TC axonal patches, and acquire an asymmetric branching morphology (Rice and Van der Loos, 1977). To evaluate the dendritic organization of layer IV neurons, Golgi analyses were done in adult RIM-DKO ${ }^{\text {Sert }}(n=4)$ and control $(n=4)$ mice. Fifty control and 41 RIM-DKO ${ }^{\text {Sert }}$ layer IV spiny stellate neurons were reconstructed and analyzed. One representative neuron for each genotype is shown in Figure 6 (Fig. 6a,b). Cells were qualified as asymmetric when $>50 \%$ of the dendrites were distributed within one quadrant (Fig. $\left.6 a, a^{\prime}, b, b^{\prime}\right)$ as described previously (Datwani et al., 2002). The percentage of asymmetric spiny stellate neurons was smaller in RIM-DKO ${ }^{\text {Sert }}$ than in control mice (Fig. $6 c, d ; 21 \%$ vs $70 \% ; n=4$ each, $p=0.028$, MannWhitney). The dendritic span of the spiny stellate neurons, 


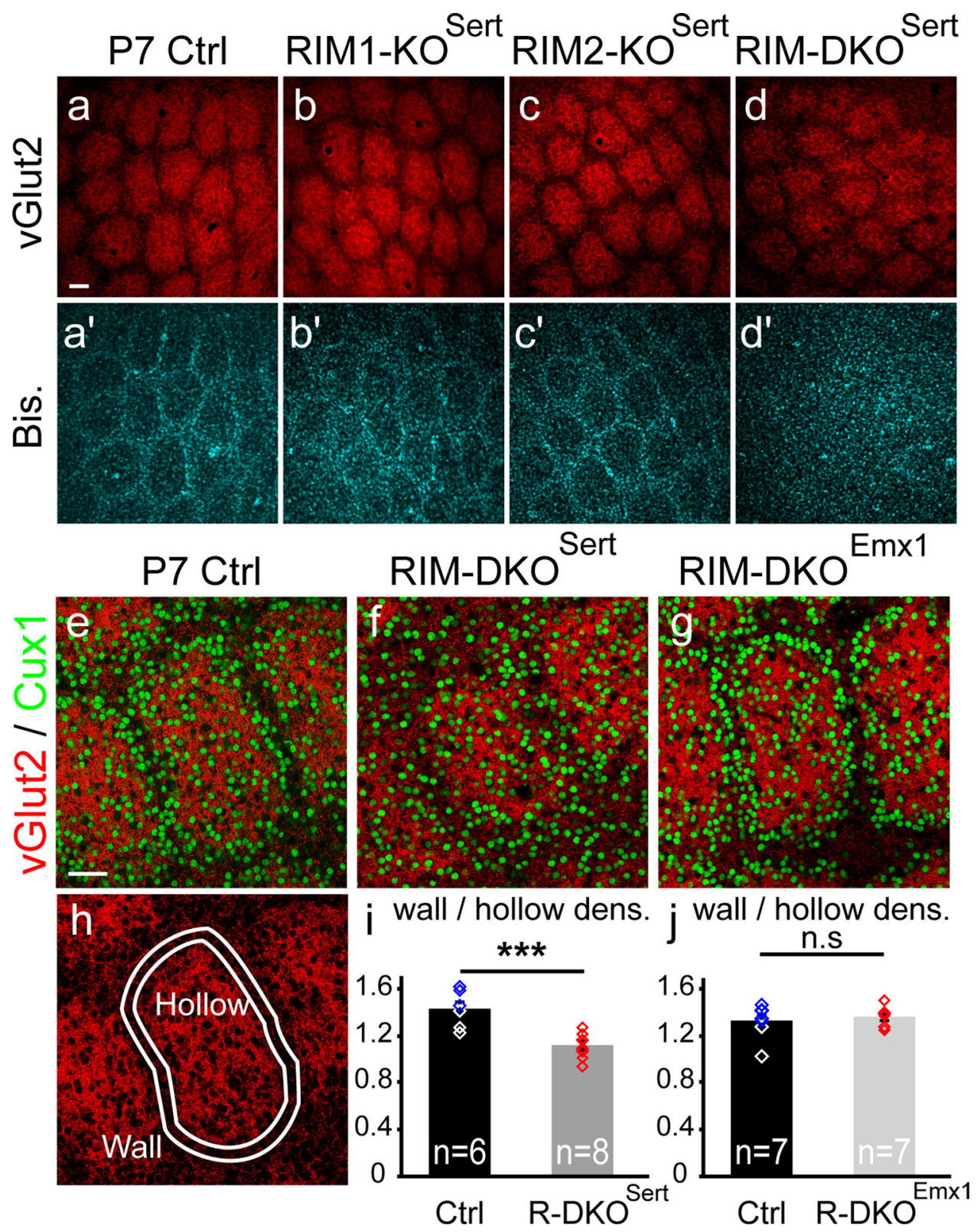

Figure 5. Deletion of RIM1-2 in the thalamus alters barrel development. Cortices from control, RIM1-KO ${ }^{\text {Sert }}$, RIM2-K0 ${ }^{\text {Sert }}$, and RIM-DKO ${ }^{\text {Sert }}$ mice were tangentially sectioned through layer IV and labeled for vGlut2 to reveal TC terminals $(\boldsymbol{a}-\boldsymbol{d})$ and DAPI to reveal the nuclei of cells in layer IV $\left(\boldsymbol{a}^{\prime}-\boldsymbol{d}^{\prime}\right)$. $\boldsymbol{a}-\boldsymbol{d}$, The whisker-related patterns as revealed with vGlut2 immunocytochemistry are similar in all 4 genotypes. In the small anterior snout barrels: $\boldsymbol{a}^{\prime}-\boldsymbol{d}^{\prime}$, DAPI staining reveals a normal barrel-like organization of layer IV cells in the control $\left(\boldsymbol{a}^{\prime}\right)$, the RIM1-K0 Sert $\left(\boldsymbol{b}^{\prime}\right)$ and the RIM2-K0 ${ }^{\text {Sert }}\left(\boldsymbol{c}^{\prime}\right)$ in the RIM-DK0 ${ }^{\text {Sert }}$ mice, however, layer IV neurons are uniformly distributed $\left(\boldsymbol{d}^{\prime}\right)$. Scale bar: $50 \mu \mathrm{m}$. (e-j) Double immunolabeling of vGlut2-positive TC axons and Cux1-positive layer IV cortical neurons in P7 tangential sections through principal barrels of the PMBSF in control $(\boldsymbol{e})$, RIM-DK0 ${ }^{\text {Sert }}(\boldsymbol{f})$ and RIM-DKO ${ }^{\mathrm{Emx} 1}(\boldsymbol{g})$ mice. The barrel-like organization of layer IV neurons is visible with Cux 1 labeling in control $(\boldsymbol{f})$ and DKO ${ }^{\mathrm{Emx}}(\boldsymbol{g})$ mice. In contrast Cux1-labeled neurons are uniformly distributed in the DKO ${ }^{\text {Sert }}$ mice $(\boldsymbol{f})$. $\boldsymbol{h}$, To estimate neuronal density in the barrel septae and hollows, a mask was computed based on the intensity of vGlut2-positive staining (the barrel hollow), and another mask was drawn surrounding it as $20-\mu \mathrm{m}$-thick band (the barrel wall). Density of neurons was counted in these 2 areas $(i, j)$. Histograms show the ratios of neuronal density between the walls and the hollows; and values were individually plotted (diamonds). This wall/hollow ratio is significantly reduced in RIM-DKO ${ }^{\text {Sert }}$ mice compared with controls (i), whereas the wall/hollow ratio is unchanged in RIM-DKO ${ }^{\text {Emx1 }}$ compared with controls $(j) .{ }^{* * *} p<0.001$; n.s., nonsignificant. Scale bars: $\boldsymbol{a}\left(\right.$ for $\left.\boldsymbol{a}-\boldsymbol{d}^{\prime}\right), \boldsymbol{e}($ for $\boldsymbol{e}-\boldsymbol{h}), 50 \mu \mathrm{m}$.

measured as the areas projected in a two-dimensional plane, was more than doubled in the RIM-DKO ${ }^{\text {Sert }}$ mice $(12,205 \pm 688$ $\left.\mu \mathrm{m}^{2}\right)$ compared with control mice $\left(5885 \pm 418 \mu \mathrm{m}^{2} ; p<0.001\right)$. This can be explained by the loss of asymmetry and by an increase in the length of dendrites visible in the Sholl analysis: dendrites of RIM-DKO ${ }^{\text {Sert }}$ mice cross circles up to $150 \mu \mathrm{m}$ diameter around the cell soma, whereas in controls the limit is $120 \mu \mathrm{m}$. In addition, dendrites from RIM-DKO ${ }^{\text {Sert }}$ neurons had more intersections than controls with every circle from 50 to $90 \mu \mathrm{m}(n=4$ for each genotype, $p<0.05$ for 50 and $90 \mu \mathrm{m} p<0.001$ for 60,70 and 80 $\mu \mathrm{m}$; Fig. 6e). Moreover, a tendency for a moderate increase in dendritic branch endpoints was noted in the RIM-DKO ${ }^{\text {Sert }}$ mice (14.2 \pm 0.7 dendrites/cell), compared with controls (13.4 \pm 0.4 dendrites/cell; $n=4$ each, $p=0.123$, Mann-Whitney) with a reduced dendritic complexity, as the number of primary branches increased (control $3.3 \pm 0.09$ dendrite/cell; RIM-DKO ${ }^{\text {Sert }}: 4.1 \pm$ $0.1 ; n=4$ each, $p=0.029$, Mann-Whitney) while the number of third and fourth degree branches was reduced (Fig. $6 f$ ). Finally, counts of the number of spines along randomly selected $20 \mu \mathrm{m}$ segments of the secondary and tertiary dendrites of the layer IV 


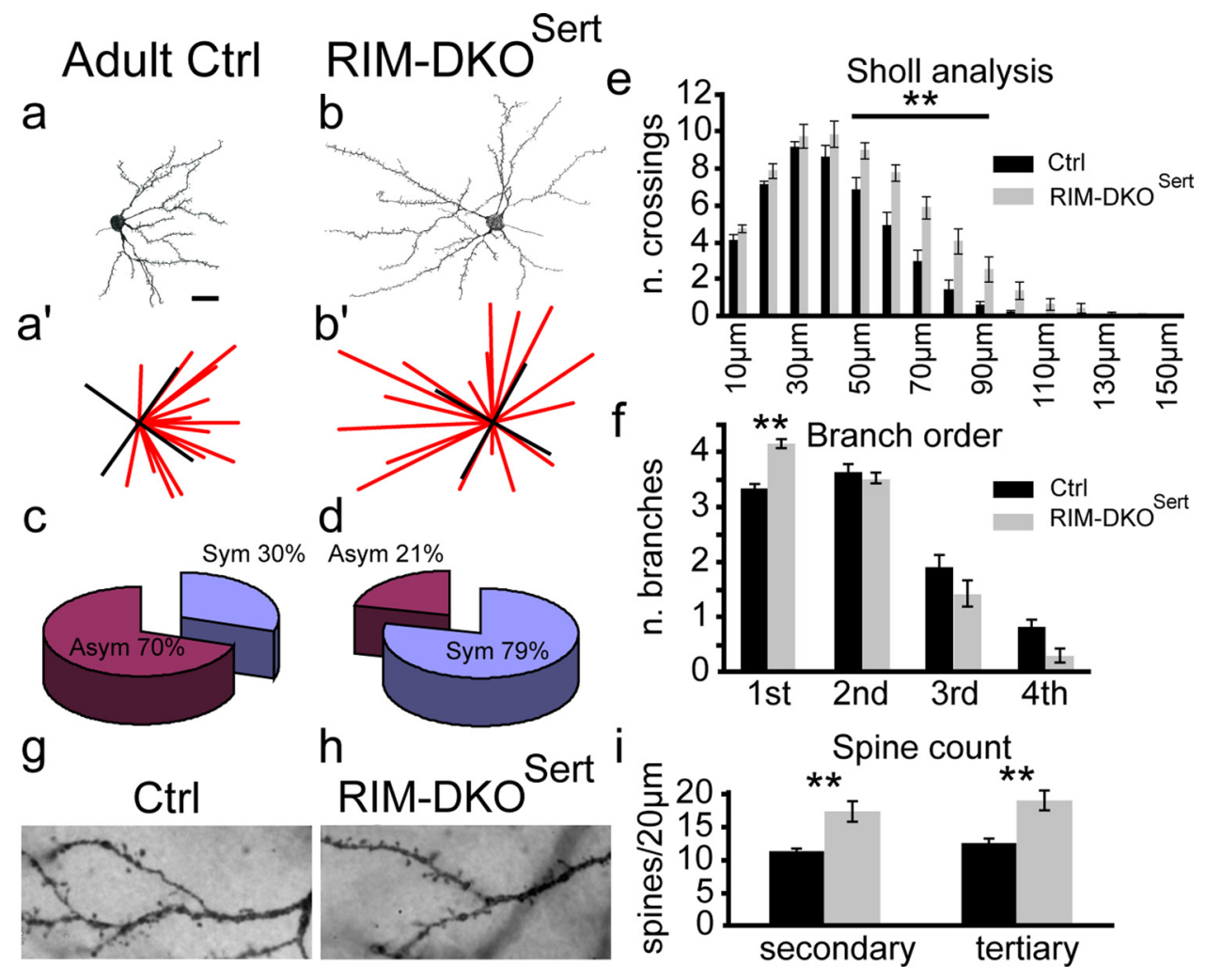

Figure 6. Morphology of layer IV cortical neurons in RIM-DKO Sert mice. $\boldsymbol{a}, \boldsymbol{b}$, Camera lucida drawings of Golgi-Cox-stained spiny stellate neurons in the barrel cortex. Typical layer IV neurons from control $(\boldsymbol{a})$ and RIM-DKO ${ }^{\text {Sert }}(\boldsymbol{b})$ are illustrated. $\left(\boldsymbol{a}^{\prime}, \boldsymbol{b}^{\prime}\right)$ to measure dendritic orientation, lines were drawn from the tip of each dendrite to the center of the cell soma; and the number of lines per quadrant was taken as an index of dendritic symmetry. $\boldsymbol{c}, \boldsymbol{d}$, The pie charts present the percentage of assymetric/symetric profiles for control (c) and RIM-DKO ${ }^{\text {Sert }}$ (d) mice. $\boldsymbol{e}$, Sholl analysis: the histograms represent the mean number ( + SEM) of dendrites crossing concentric rings drawn at $10 \mu \mathrm{m}$ intervals from the cell soma. $f$, Histogram depicting the mean + SEM of first, second, third, and fourth order dendritic branches of spiny stellate neurons in control and DKO ${ }^{\text {Sert }}$ mice. $\boldsymbol{g}, \boldsymbol{h}$, micrographs of Golgi stained second and third order dendrites. Spines appear to be more numerous in the RIM-DKO ${ }^{\text {Sert }}$ neurons $(\boldsymbol{h})$, than in controls $(\boldsymbol{g}) . \boldsymbol{i}$, Histogram of the mean + SEM spine counts on $20-\mu \mathrm{m}$-long sections of second and third order dendrites of neurons from RIM-DKO $0^{\text {Sert }}$ and control brains. ${ }^{* *} p<0.05$. Scale bar, $20 \mu \mathrm{m}$.

neurons (Fig. $6 g, h$ ) showed a significant increase in the density of spines in the RIM-DKO ${ }^{\text {Sert }}$ compared with control mice [Fig. $6 i$, secondary: $17.4 \pm 1.4$ vs $11.5 \pm 0.4$ spine $/ 20 \mu \mathrm{m}$ for controls, $n=$ 4 each, $p=0.0143$; tertiary: $19.1 \pm 1.5(n=3)$ vs $12.7 \pm 0.7$ for controls $(n=4)$ spine $/ 20 \mu \mathrm{m}$, each, $p=0.0286$; Mann-Whitney tests].

These results suggest that reduced efficacy of synaptic transmission at the TC synapse causes significant structural changes in the dendritic differentiation and organization of layer IV spiny stellate neurons, with a lack of acquisition of a polarized dendritic arborization, and an increase in branch and spine numbers.

Sensory-evoked responses are altered in RIM-DKO ${ }^{\text {Sert }}$ mice To evaluate the long term consequences of altered presynaptic release at the TC synapse on processing of somatosensory information, we performed in vivo voltage-sensitive dye (VSD) imaging of cortical activity evoked by tactile sensory stimulation. This method is based on the use of dye molecules that transduce membrane potential changes into optical fluorescent signals (Grinvald and Hildesheim, 2004). Using conventional epifluorescence optics on the mouse cortex in vivo, it allows the visualization of membrane potential changes occurring in superficial layers (Ferezou et al., 2006). A large part of the left dorsal cortical surface, covering most of the sensorimotor cortex, was imaged under urethane anesthesia using the dye RH1691. As previously described (Ferezou et al., 2007), a single right C2 whisker deflection induced a short latency $(8-12 \mathrm{~ms})$ response in the $\mathrm{C} 2$ barrel column of the contralateral PMBSF (S1; Fig. 7a). The amplitude of this response was significantly reduced in RIM-DKO ${ }^{\text {Sert }}$ mice $(n=5)$ compared with control animals $(n=4, p=0.049$; Fig. $7 b, c)$, although its location and latency were not modified. Within $28 \mathrm{~ms}$ after whisker stimulation, the evoked activity spreads within the entire S1, and propagates toward the whisker motor cortex (M1). This propagation of the activity was unchanged in RIM-DKO ${ }^{\text {Sert }}$ mice compared with controls (Fig. $7 b, d)$. These results showed that although there is a significant reduction of the amplitude of the sensory driven responses in the RIM-DKO ${ }^{\text {Sert }}$ mice, the spatiotemporal dynamics of the intracortical activity was unchanged.

We also tested the consequences of this reduced thalamic synaptic drive on the activity-modulated gene expression. Expression of immediate early genes such as c-Fos is triggered in the somatosensory cortex, and in layer IV in particular, by sensory exploration in naturalistic conditions (Staiger et al., 2000). Mice were placed in an environment containing several objects that differed by their textures and shape and c-Fos expression was evaluated $1 \mathrm{~h}$ later. To identify the response to sensory exploration versus nonspecific activation of cortical neurons, all whiskers were clipped on one side of the snout. In control mice, there was a fivefold increase in the number of c-Fos-positive neurons in the $S 1$ region of the unclipped side relative to the clipped side (Fig. $8 a, a^{\prime}, c$ ). In RIM-DKO ${ }^{\text {Sert }}$ mice, c-Fos expression in layer IV was strongly reduced in both the clipped and the unclipped sides (Fig. $8 b, b^{\prime}, c$ ), in comparison with controls, although a small de- 


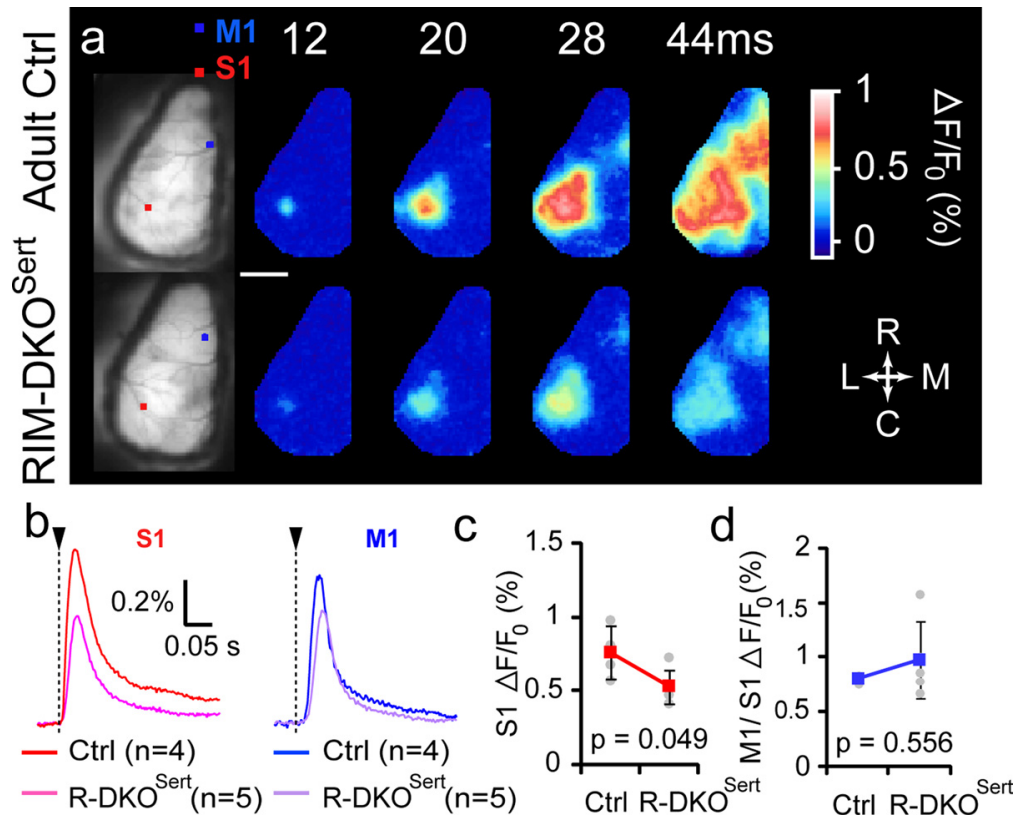

Figure 7. Cortical sensory processing is altered in RIM-DKO ${ }^{\text {Sert }}$ mice. $\boldsymbol{a}$, VSD imaging of cortical activity evoked by single whisker (C2) deflection in control and RIM-DKO ${ }^{\text {Sert }}$ mice. Typical responses are illustrated in the upper panel: the first images on the left show resting fluorescence of VSD-stained unilateral craniotomies. The squares indicate the regions of interest used to quantify the signal on the $\mathrm{C} 2$ barrel column of the primary somatosensory cortex (S1, red square) and in the primary motor cortex (M1, blue square). Adjacent images show the VSD fluorescence changes at different times following a single right C2 whisker deflection. Scale bar, $2 \mathrm{~mm}$. $\boldsymbol{b}$, Averaged responses from control mice and RIM-DKO ${ }^{\text {Sert }}$ mice, quantified from S1 (left) and M1 (right). c, Peak amplitudes of the sensory responses measured in $\mathbf{S 1} . \boldsymbol{d}$, Ratio M1/S1 (means \pm SD for each group).

gree of activation could be noted when comparing the clipped/ unclipped side of the mutants, which may be related to the residual transmission in nonrecombined neurons (estimated to $4-11 \%$, see Results, Region specific deletion of RIM genes). These results indicated that reduced transmitter release at the TC synapse profoundly impacts activity-dependent gene expression in the layer IV of the somatosensory cortex.

Overall, these experiments indicated that decreased neurotransmitter release at the TC synapse, diminished sensory-evoked responses but had even stronger effects on the activity-dependent gene expression which was almost abolished.

\section{Behavioral consequences in RIM-DKO ${ }^{\text {Sert }}$ mice}

To evaluate the functional consequences of the morphological and physiological changes of sensory processing on behavior, we began by examining motor exploratory behavior of the adult mice when placed in a familiar nonstressful context containing novel objects to explore. Total locomotor behavior, measured with video tracking, was unchanged in the RIM-DKO ${ }^{\text {Sert }}(3.8 \pm$ $0.4 \mathrm{~mm} / \mathrm{s} n=9)$ compared with controls $(3.8 \pm 0.3 \mathrm{~mm} / \mathrm{s} n=9$; Fig. $8 d$ ), and animals whisked while exploring the novel objects. However, interestingly the time spent exploring these novel objects was increased in the RIM-DKO ${ }^{\text {Sert }}(44 \pm 16 \mathrm{~s} n=9)$ compared with controls $(25 \pm 7 s ; n=8, p=0.043$; Fig. $8 e$ ). This increase is consistent with observations of increased thigmotaxis in rats that have undergone a lesion of the primary somatosensory cortex (Luhmann et al., 2005), and can be interpreted as indicating defective sensory integration. To further evaluate sensorimotor performance, we tested mice in the beam walking test, that has previously been noted to be disturbed in barrelless MAOA-KO mice and normalized in MAOA-5-HT1B DKO with rescued barrel formation (Salichon et al., 2001). During success- ful trials, the RIM-DKO ${ }^{\text {Sert }}$ took a significantly longer time to traverse the beam $(34.44 \pm 9.3 \mathrm{~s}, n=8, p=0.037) \mathrm{com}-$ pared with their control littermates $(9.86 \pm 4.3 \mathrm{~s}, n=7$; Fig. $8 f)$. In addition, Rim-DKO ${ }^{\text {Sert }}$ mice had a strong probability to fail crossing the beam on a given trial $(29.6 \pm 11.7 \%, n=9, p=0.016)$ compared with controls (no failure, $n=$ 8; Fig. $8 g$ ).

These results indicated that although general motor activity was not visibly altered in the RIM-DKO ${ }^{\text {Sert }}$, sensorimotor integration was defective in these mice.

\section{Discussion}

Using regional ablation of the RIM1 and RIM2 proteins at TC or corticocortical synapses, we find that synaptic release at TC but not at corticocortical synapses is necessary for the formation of barrels as cellular specializations in the mouse neocortex. Our results also show that presynaptic control of TC transmission is dispensable for the formation of a topographic map by the incoming TC axons. Decreased evoked release at the TC synapse almost abolished sensoryevoked immediate early gene expression in the cortex.

\section{Presynaptic release is required at TC but not corticocortical} synapses for barrel formation

The importance of synaptic glutamate release for barrel development has previously been suggested in mutants with defective synaptic release at the TC synapse (Lu et al., 2006; Erzurumlu and Gaspar, 2012). However, a causal link was difficult to establish because of the pleiotropic effects of these mutations. Our observations stress the importance of the TC synaptic input for the refinement of cortical circuits in the barrel cortex, since the thalamus-specific deletion of RIM1 and RIM2 affected the cortical barrel structure whereas cortex-specific deletion did not. TC synapses have a high probability of release early in development, before barrel emergence (Laurent et al., 2002; Yanagisawa et al., 2004) at a critical period when they evoke long-term potentiation (LTP) (Crair and Malenka, 1995). Thus, perturbing the efficiency of this synapse is likely to have important consequences on the plasticity of the postsynaptic cortical neurons. At the time of barrel cortex development, a spindle-like network activity has been recorded in the S1 cortex (Khazipov et al., 2004; Minlebaev et al., 2007; Yang et al., 2009). This activity is driven by the thalamic afferents and the stimulation of the whisker pads (Minlebaev et al., 2011), and is therefore well suited to play a driving role in the establishment of a columnar organization in the cerebral cortex.

Because a vast majority of the glutamatergic synapses in the cerebral cortex and in the barrel field in particular, are corticocortical (Benshalom and White, 1986; Douglas et al., 1986) it appeared surprising that RIM deletion in excitatory neurons of the cerebral cortex in RIM-DKO ${ }^{\mathrm{Emxl}}$ had no visible effect on the normal development of the barrel architecture. This indicated that neurotransmitter release by intrinsic corticocortical barrel circuits, and subplate to layer IV connections which amplify tha- 


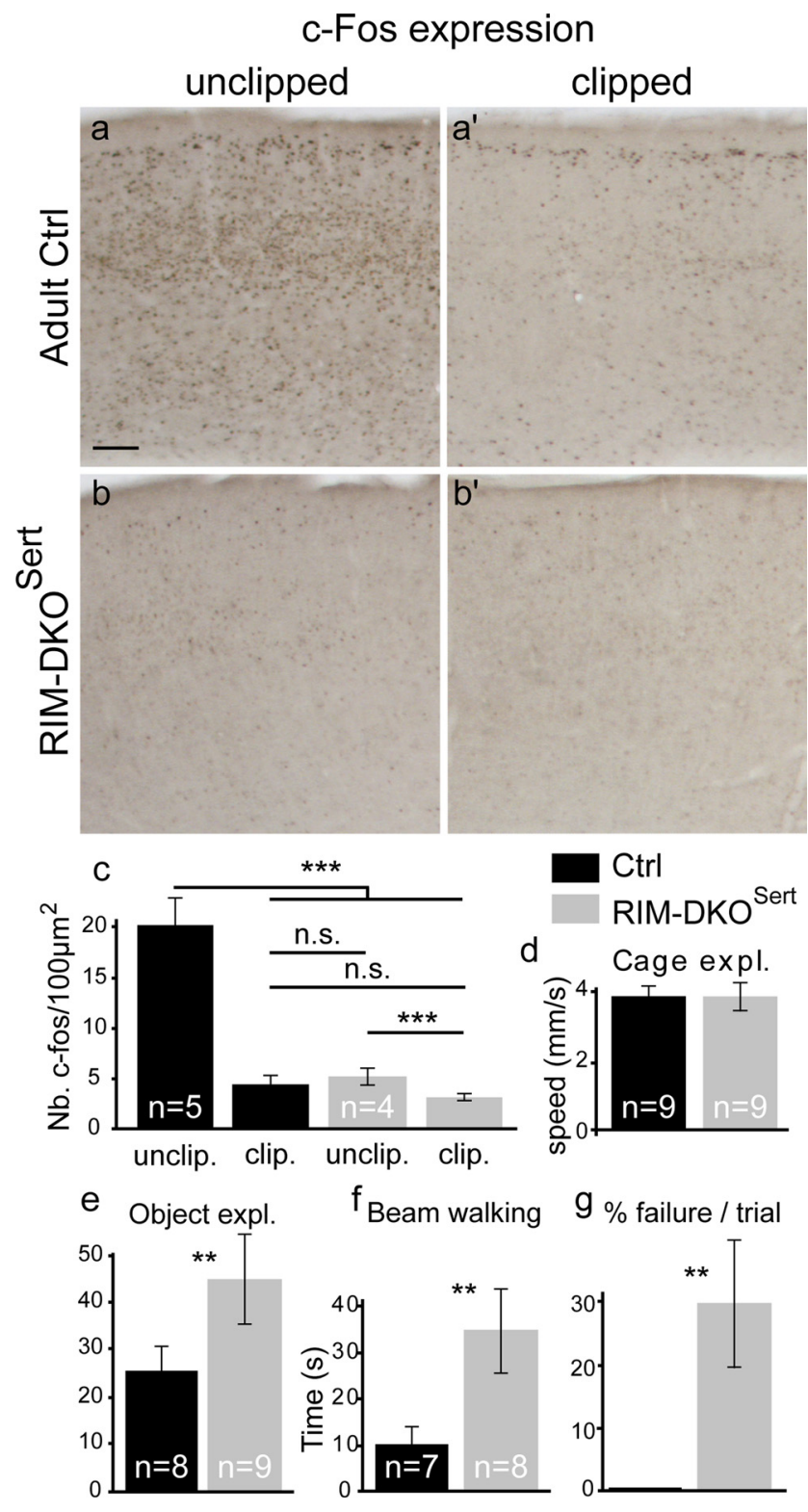

Figure 8. Reduced activity-dependent expression of c-Fos in the somatosensory cortex and altered sensory-motor behavior. $\boldsymbol{a}-\boldsymbol{b}^{\prime}$, Adult mice had all whiskers clipped on one side of the snout, and were placed $1 \mathrm{~h}$ in an enriched environment the following day. c-Fos immunoreactivity was revealed on coronal brain sections through the primary somatosensory cortex of the unclipped (contralateral, $\boldsymbol{a}$, $\boldsymbol{b}$ ) and clipped (ipsilateral, $\left.\boldsymbol{a}^{\prime}, \boldsymbol{b}^{\prime}\right)$ sides in control $\left(\boldsymbol{a}, \boldsymbol{a}^{\prime}\right)$ and RIM-DKO $0^{\text {Sert }}$ mice $\left(\boldsymbol{b}, \boldsymbol{b}^{\prime}\right)$. $\boldsymbol{c}$, Density estimates of $c$-Fos labeled neurons (mean + SEM) in layer IV from 5 control and 6 recombined mice, shows a significant increase in the S1 cortex corresponding to the unclipped whisker. In the RIMDKO ${ }^{\text {Sert }}$ c-Fos expression on both sides is similar to the clipped side of the control. However c-Fos activation is detectable in the mutants when the clipped side is compared with unclipped side. $\boldsymbol{d}$, General exploratory behavior. Mice of both genotypes did not differ in terms of general activity and exploration, as estimated by videotracking in a box during 10 min sessions. $\boldsymbol{e}$, Exploration of novel objects. The time exploring new objects was increased in the RIM-DKO ${ }^{\text {Sert }}$ mice compared with controls. $\boldsymbol{f}, \boldsymbol{g}$, Beam walking test. RIM-DKO ${ }^{\text {Sert }}$ needed more time than controls to cross the beam successfully $(\boldsymbol{f})$. Moreover, RIM-DKO ${ }^{\text {Sert }}$ mice showed a high probability of failure to cross within the 2 min trial, whereas control showed a very low incidence of failures (g). Scale bar: (in $\boldsymbol{a}) \boldsymbol{a}-\boldsymbol{b}^{\prime}, 125 \mu \mathrm{m}$. ${ }^{* * *} p<0.001 ;{ }^{* *} p<0.05$.

lamic inputs (Schubert et al., 2003; Lefort et al., 2009; Luhmann et al., 2009; Zhao et al., 2009; Sehara et al., 2010) do not play a major role in the establishment of the cellular organization of layer IV neurons as barrels. However it is not excluded that cortical RIMs play a role in other aspects of cortical wiring that were not examined here.
Our observations suggest that there is a functional redundancy of RIM1 and RIM2 proteins at the developing TC synapse. Indeed, both RIM1 and RIM2 genes are expressed in the VB during barrel development, and selective ablation of either RIM1 or RIM2 genes in the thalamus is insufficient to cause visible barrel alterations. This functional redundancy is consistent with previous observations investigating the role of RIM proteins in the control of key steps of presynaptic organization and function (Schoch et al., 2006; Kaeser et al., 2011).

Thalamus-specific removal of RIMs alter barrel development and dendritic maturation but not patterning of thalamic afferents

Barrel cortex development involves the coordinated maturation of the presynaptic and postsynaptic neuronal elements. Presynaptically, the TC axon terminals segregate into terminal patches, and postsynaptically, the spiny stellate neurons in layer IV become distributed around these TC patches and acquire a polarized orientation of their dendrites. The changes found in the RIM-DKO ${ }^{\text {sert }}$ indicated a dissociation of these two developmental processes: the TC patches were well segregated in contrast to the absence of cellular barrels, reminiscent of changes observed after cortical-specific deletion of glutamate receptors (review in Inan et al., 2006, Erzurumlu and Gaspar, 2012).

The observation of well segregated TC patches corresponding to whisker domains in the RIM-DKO ${ }^{\text {Sert }}$ mice questions the notion that presynaptic plasticity mechanisms play a key role in the whisker-related patterning of TC afferents. This assumption was based on previous observations in mutants with defective presynaptic function (Laurent et al., 2002; Lu et al., 2006) and altered segregation of the TC axons. In MAOA KO (Cases et al., 1996; Rebsam et al., 2002) and AC1 KO mice (Welker et al., 1996; Gheorghita et al., 2006), TC axons invade the space between barrels. A proposed model for these changes was that TC afferents are selectively strengthened or destabilized based on their release probability ( $\mathrm{Lu}$ et al., 2006). This implies that spike timingdependent learning rules (long-term potentiation/depression) play a causal (instructive) role in TC axon segregation. However, in the RIM-DKO ${ }^{\text {Sert }}$ the high incidence of synaptic failures at the TC synapses is likely to disrupt Hebbian spatio-temporal coding that strengthens coactive afferents and weakens others. Thus, it is more likely that axon guidance molecules, rather than synaptic consolidation, are the main drivers for clustering TC afferents into periphery related patterns. This interpretation is also supported by observations showing that signaling via presynaptic TC 5 -HT1b receptors and AC1 modify axonal responses to guidance molecules such as the ephrins or netrin (Nicol et al., 2006; Bonnin et al., 2007).

However our observations do not completely rule out the role of neurotransmitter release in shaping terminal axons since there was a residual $30 \%$ release at the TC synapses of the RIM-DKO ${ }^{\text {Sert }}$ mice. Moreover, spontaneous release may still occur, although it is strongly reduced in the absence of RIM proteins (Deng et al., 2011), and our present observations showed a reduced size of the individual TC patches. A possibility would then be that either the residual glutamate release in TC axons of the RIM-DKO ${ }^{\text {Sert }}$ is sufficient to enable axon growth-mediated mechanisms that form patch-like structures, or that a low synaptic activity equally affecting all TC inputs is not sufficient to perturb activity-dependent competitive interactions among all incoming afferents.

Interestingly, the space between the TC axonal patches was increased in RIM-DKO ${ }^{\text {Sert }}$ mice, raising the intriguing possibility that this could result from a competition for cortical space be- 
tween cortical and thalamic axons making synaptic contacts onto layer IV neurons. For instance, corticocortical afferents from callosal axons, or layer II/III neurons, occupy complementary domains to the TC afferents, in the septa of the barrel cortex (Koralek and Killackey, 1990; Sehara et al., 2010) whose maintained synaptic release properties may increase relative to the TC afferents in the RIM-DKO ${ }^{\text {Sert }}$.

The formation of barrels in the mouse somatosensory cortex involves the formation of a cylindrical array ("barrel") of layer IV spiny stellate neurons, with neurons along the walls orienting their dendritic arbors to the center. In RIM-DKO ${ }^{\text {Sert }}$ mice, dendritic orientation failed to form. This phenotype is similar to the one observed in mice with cortex-specific deletion of NR1 or mGluR5 genes (Datwani et al., 2002; Ballester-Rosado et al., 2010), where all cortical neurons are invalidated for the receptor. Here, similar dendritic defects occurred in a noncell autonomous fashion: weakening or failure at the presynaptic thalamic level is likely to affect signaling downstream of both NMDA and mGluR5 receptors, but exclusively at the TC synapse. Together, these results implicate a major role for the neural activity imposed by the thalamic afferents rather that cortical afferents in sculpting cellular patterns and dendritic orientation of layer IV spiny stellate cells.

\section{Functional consequences of thalamus-specific removal of RIMs}

Deletion of the RIM genes from the sensory thalamus resulted in a permanent reduction of sensory-driven cortical activation, in voltage-sensitive dye experiments. However, the spatio-temporal patterning of the somatosensory-evoked responses was undisturbed. In contrast, stimulus-evoked changes in immediate early gene expression were profoundly altered, as shown by the lack of c-Fos expression in the somatosensory cortex of the RIM$\mathrm{DKO}^{\text {sert }}$ after sensory stimulation. The difference in amplitude of the detected changes with two methods can be explained by the fact that activity-dependent expression of the immediate early genes requires a sufficient level and specific temporal pattern of neuronal depolarization (Fields et al., 2005), whereas VSD signals are graded to activity levels (Ferezou et al., 2006). Alterations in activity-dependent triggering of gene expression could be an entry point to the structural defects observed in the barrel cortex. Modifications of c-Fos and downstream signaling have previously been shown to be implicated in dendrite and spine structural organization (Wong and Ghosh, 2002; Iwasato et al., 2008).

Behavioral investigations indicated that sensory integration was strongly disturbed in the RIM-DKO ${ }^{\text {Sert }}$, as reflected by the increased exploration, and the poor motor behavior on the beam walking test (Goldstein, 1993; Luhmann et al., 2005). The deficits could result either from the structural developmental defects or from the dampening of the sensory-evoked responses from the $\mathrm{VB}$, and the reduced accuracy of temporal coding.

\section{Conclusion}

Our results show that RIM1/RIM2-mediated synaptic release at the TC but not at the corticocortical synapses is necessary for the formation of barrels as cellular specializations in the mouse neocortex, but that it is dispensable for the formation of a precise topographic map and for normal TC synapse development. Altogether, this indicated that the control of presynaptic release is crucial both for the development of the neuronal network structure and its function.

\section{References}

Ballester-Rosado CJ, Albright MJ, Wu CS, Liao CC, Zhu J, Xu J, Lee LJ, Lu HC (2010) mGluR5 in cortical excitatory neurons exerts both cell- autonomous and -nonautonomous influences on cortical somatosensory circuit formation. J Neurosci 30:16896-16909.

Benshalom G, White EL (1986) Quantification of thalamocortical synapses with spiny stellate neurons in layer IV of mouse somatosensory cortex. J Comp Neurol 253:303-314.

Bonnin A, Torii M, Wang L, Rakic P, Levitt P (2007) Serotonin modulates the response of embryonic thalamocortical axons to netrin-1. Nat Neurosci 10:588-597.

Borodinsky LN, Root CM, Cronin JA, Sann SB, Gu X, Spitzer NC (2004) Activity-dependent homeostatic specification of transmitter expression in embryonic neurons. Nature 429:523-530.

Bourgeron T (2009) A synaptic trek to autism. Curr Opin Neurobiol 19:231-234.

Carter RJ, Morton J, Dunnett SB (2001) Motor coordination and balance in rodents. Curr Protoc Neurosci Chapter 8:Unit 8.12.

Cases O, Vitalis T, Seif I, De Maeyer E, Sotelo C, Gaspar P (1996) Lack of barrels in the somatosensory cortex of monoamine oxidase A-deficient mice: role of a serotonin excess during the critical period. Neuron 16:297-307.

Crair MC, Malenka RC (1995) A critical period for long-term potentiation at thalamocortical synapses. Nature 375:325-328.

Crossin KL, Hoffman S, Tan SS, Edelman GM (1989) Cytotactin and its proteoglycan ligand mark structural and functional boundaries in somatosensory cortex of the early postnatal mouse. Dev Biol 136:381-392.

Datwani A, Iwasato T, Itohara S, Erzurumlu RS (2002) NMDA receptordependent pattern transfer from afferents to postsynaptic cells and dendritic differentiation in the barrel cortex. Mol Cell Neurosci 21:477-492.

Deng L, Kaeser PS, Xu W, Südhof TC (2011) RIM proteins activate vesicle priming by reversing autoinhibitory homodimerization of Munc13. Neuron 69:317-331.

Douglas R, Markram H, Martin K (1986) Neocortex. In: The synaptic organization of the brain (Shepherd GM, ed), pp 455-498. New York: Oxford UP.

Erzurumlu RS, Gaspar P (2012) Development and critical period plasticity of the barrel cortex. Eur J Neurosci (in press).

Erzurumlu RS, Kind PC (2001) Neural activity: sculptor of 'barrels' in the neocortex. Trends Neurosci 24:589-595.

Evrard A, Ropert N (2009) Early development of the thalamic inhibitory feedback loop in the primary somatosensory system of the newborn mice. J Neurosci 29:9930-9940.

Ferezou I, Bolea S, Petersen CC (2006) Visualizing the cortical representation of whisker touch: voltage-sensitive dye imaging in freely moving mice. Neuron 50:617-629.

Ferezou I, Haiss F, Gentet LJ, Aronoff R, Weber B, Petersen CC (2007) Spatiotemporal dynamics of cortical sensorimotor integration in behaving mice. Neuron 56:907-923.

Ferrere A, Vitalis T, Gingras H, Gaspar P, Cases O (2006) Expression of Cux-1 and Cux-2 in the developing somatosensory cortex of normal and barrel-defective mice. Anat Rec A Discov Mol Cell Evol Biol 288:158 -165.

Fields RD, Neale EA, Nelson PG (1990) Effects of patterned electrical activity on neurite outgrowth from mouse sensory neurons. J Neurosci 10:2950-2964.

Gheorghita F, Kraftsik R, Dubois R, Welker E (2006) Structural basis for map formation in the thalamocortical pathway of the barrelless mouse. J Neurosci 26:10057-10067.

Goldstein LB (1993) Rapid reliable measurement of lesion parameters for studies of motor recovery after sensorimotor cortex injury in the rat. J Neurosci Methods 48:35-42.

Grinvald A, Hildesheim R (2004) VSDI: a new era in functional imaging of cortical dynamics. Nat Rev Neurosci 5:874-885.

Han Y, Kaeser PS, Südhof TC, Schneggenburger R (2011) RIM determines $\mathrm{Ca}(2)+$ channel density and vesicle docking at the presynaptic active zone. Neuron 69:304-316.

Hannan AJ, Blakemore C, Katsnelson A, Vitalis T, Huber KM, Bear M, Roder J, Kim D, Shin HS, Kind PC (2001) PLC-beta1, activated via mGluRs, mediates activity-dependent differentiation in cerebral cortex. Nat Neurosci 4:282-288.

Hanson MG, Landmesser LT (2004) Normal patterns of spontaneous activity are required for correct motor axon guidance and the expression of specific guidance molecules. Neuron 43:687-701.

Hippenmeyer S, Vrieseling E, Sigrist M, Portmann T, Laengle C, Ladle DR, Arber S (2005) A developmental switch in the response of DRG neurons to ETS transcription factor signaling. PLoS Biol 3:e159. 
Inan M, Lu HC, Albright MJ, She WC, Crair MC (2006) Barrel map development relies on protein kinase A regulatory subunit II beta-mediated cAMP signaling. J Neurosci 26:4338-4349.

Iwasato T, Datwani A, Wolf AM, Nishiyama H, Taguchi Y, Tonegawa S, Knöpfel T, Erzurumlu RS, Itohara S (2000) Cortex-restricted disruption of NMDAR1 impairs neuronal patterns in the barrel cortex. Nature 406:726-731.

Iwasato T, Inan M, Kanki H, Erzurumlu RS, Itohara S, Crair MC (2008) Cortical adenylyl cyclase 1 is required for thalamocortical synapse maturation and aspects of layer IV barrel development. J Neurosci 28:5931-5943.

Kaeser PS, Kwon HB, Chiu CQ, Deng L, Castillo PE, Südhof TC (2008) RIMlalpha and RIMlbeta are synthesized from distinct promoters of the RIM1 gene to mediate differential but overlapping synaptic functions. J Neurosci 28:13435-13447.

Kaeser PS, Deng L, Wang Y, Dulubova I, Liu X, Rizo J, Südhof TC (2011) RIM proteins tether $\mathrm{Ca} 2+$ channels to presynaptic active zones via a direct PDZ-domain interaction. Cell 144:282-295.

Khazipov R, Sirota A, Leinekugel X, Holmes GL, Ben-Ari Y, Buzsáki G (2004) Early motor activity drives spindle bursts in the developing somatosensory cortex. Nature 432:758-761.

Kidd FL, Isaac JT (1999) Developmental and activity-dependent regulation of kainate receptors at thalamocortical synapses. Nature 400:569-573.

Koralek KA, Killackey HP (1990) Callosal projections in rat somatosensory cortex are altered by early removal of afferent input. Proc Natl Acad Sci U S A 87:1396-1400.

Laurent A, Goaillard JM, Cases O, Lebrand C, Gaspar P, Ropert N (2002) Activity-dependent presynaptic effect of serotonin $1 \mathrm{~B}$ receptors on the somatosensory thalamocortical transmission in neonatal mice. J Neurosci 22:886-900.

Lebrand C, Cases O, Wehrlé R, Blakely RD, Edwards RH, Gaspar P (1998) Transient developmental expression of monoamine transporters in the rodent forebrain. J Comp Neurol 401:506-524.

Lefort S, Tomm C, Floyd Sarria JC, Petersen CC (2009) The excitatory neuronal network of the $\mathrm{C} 2$ barrel column in mouse primary somatosensory cortex. Neuron 61:301-316.

Livak KJ, Schmittgen TD (2001) Analysis of relative gene expression data using real-time quantitative PCR and the 2(-Delta Delta C(T)) Method. Methods 25:402-408.

Lu HC, Butts DA, Kaeser PS, She WC, Janz R, Crair MC (2006) Role of efficient neurotransmitter release in barrel map development. J Neurosci 26:2692-2703.

Luhmann HJ, Huston JP, Hasenöhrl RU (2005) Contralateral increase in thigmotactic scanning following unilateral barrel-cortex lesion in mice. Behav Brain Res 157:39-43.

Luhmann HJ, Kilb W, Hanganu-Opatz IL (2009) Subplate cells: amplifiers of neuronal activity in the developing cerebral cortex. Front Neuroanat 3:19.

Minlebaev M, Ben-Ari Y, Khazipov R (2007) Network mechanisms of spindle-burst oscillations in the neonatal rat barrel cortex in vivo. J Neurophysiol 97:692-700.

Minlebaev M, Colonnese M, Tsintsadze T, Sirota A, Khazipov R (2011) Early gamma oscillations synchronize developing thalamus and cortex. Science 334:226-229.

Mittelstaedt T, Alvaréz-Baron E, Schoch S (2010) RIM proteins and their role in synapse function. Biol Chem 391:599-606.

Molnár Z, López-Bendito G, Small J, Partridge LD, Blakemore C, Wilson MC (2002) Normal development of embryonic thalamocortical connectivity in the absence of evoked synaptic activity. J Neurosci 22:10313-10323.

Nahmani M, Erisir A (2005) VGluT2 immunochemistry identifies thalamocortical terminals in layer 4 of adult and developing visual cortex. J Comp Neurol 484:458-473.

Narboux-Nême N, Pavone LM, Avallone L, Zhuang X, Gaspar P (2008) Serotonin transporter transgenic (SERTcre) mouse line reveals developmental targets of serotonin specific reuptake inhibitors (SSRIs). Neuropharmacology 55:994-1005.

Nicol X, Muzerelle A, Rio JP, Métin C, Gaspar P (2006) Requirement of adenylate cyclase 1 for the ephrin-A5-dependent retraction of exuberant retinal axons. J Neurosci 26:862-872.

Nicol X, Voyatzis S, Muzerelle A, Narboux-Nême N, Südhof TC, Miles R, Gaspar P (2007) cAMP oscillations and retinal activity are permissive for ephrin signaling during the establishment of the retinotopic map. Nat Neurosci 10:340-347.

Nieto M, Monuki ES, Tang H, Imitola J, Haubst N, Khoury SJ, Cunningham J, Gotz M, Walsh CA (2004) Expression of Cux-1 and Cux-2 in the subventricular zone and upper layers II-IV of the cerebral cortex. J Comp Neurol 479:168-180.

Rebsam A, Seif I, Gaspar P (2002) Refinement of thalamocortical arbors and emergence of barrel domains in the primary somatosensory cortex: a study of normal and monoamine oxidase a knock-out mice. J Neurosci 22:8541-8552.

Rice FL, Van der Loos H (1977) Development of the barrels and barrel field in the somatosensory cortex of the mouse. J Comp Neurol 171:545-560.

Salichon N, Gaspar P, Upton AL, Picaud S, Hanoun N, Hamon M, De Maeyer E, Murphy DL, Mossner R, Lesch KP, Hen R, Seif I (2001) Excessive activation of serotonin (5-HT) $1 \mathrm{~B}$ receptors disrupts the formation of sensory maps in monoamine oxidase a and 5-ht transporter knock-out mice. J Neurosci 21:884-896.

Schoch S, Deák F, Königstorfer A, Mozhayeva M, Sara Y, Südhof TC, Kavalali ET (2001) SNARE function analyzed in synaptobrevin/VAMP knockout mice. Science 294:1117-1122.

Schoch S, Mittelstaedt T, Kaeser PS, Padgett D, Feldmann N, Chevaleyre V, Castillo PE, Hammer RE, Han W, Schmitz F, Lin W, Südhof TC (2006) Redundant functions of RIM1alpha and RIM2alpha in $\mathrm{Ca}(2+)$-triggered neurotransmitter release. EMBO J 25:5852-5863.

Schubert D, Kötter R, Zilles K, Luhmann HJ, Staiger JF (2003) Cell type-specific circuits of cortical layer IV spiny neurons. J Neurosci 23:2961-2970.

Sehara K, Toda T, Iwai L, Wakimoto M, Tanno K, Matsubayashi Y, Kawasaki $\mathrm{H}$ (2010) Whisker-related axonal patterns and plasticity of layer $2 / 3$ neurons in the mouse barrel cortex. J Neurosci 30:3082-3092.

Senft SL, Woolsey TA (1991) Growth of thalamic afferents into mouse barrel cortex. Cereb Cortex 1:308-335.

Sholl DA (1953) Dendritic organization in the neurons of the visual and motor cortices of the cat. J Anat 87:387-406.

Silver RA, Cull-Candy SG, Takahashi T (1996) Non-NMDA glutamate receptor occupancy and open probability at a rat cerebellar synapse with single and multiple release sites. J Physiol 494:231-250.

Staiger JF, Bisler S, Schleicher A, Gass P, Stehle JH, Zilles K (2000) Exploration of a novel environment leads to the expression of inducible transcription factors in barrel-related columns. Neuroscience 99:7-16.

Steindler DA, O’Brien TF, Laywell E, Harrington K, Faissner A, Schachner M (1990) Boundaries during normal and abnormal brain development: in vivo and in vitro studies of glia and glycoconjugates. Exp Neurol 109:35-56.

Sudhof TC (2004) The synaptic vesicle cycle. Annu Rev Neurosci 27:509-547.

Takahashi T (1992) The minimal inhibitory synaptic currents evoked in neonatal rat motoneurones. J Physiol 450:593-611.

Verhage M, Maia AS, Plomp JJ, Brussaard AB, Heeroma JH, Vermeer H, Toonen RF, Hammer RE, van den Berg TK, Missler M, Geuze HJ, Südhof TC (2000) Synaptic assembly of the brain in the absence of neurotransmitter secretion. Science 287:864-869.

Welker E, Armstrong-James M, Bronchti G, Ourednik W, GheorghitaBaechler F, Dubois R, Guernsey DL, Van der Loos H, Neumann PE (1996) Altered sensory processing in the somatosensory cortex of the mouse mutant barrelless. Science 271:1864-1867.

Wong RO, Ghosh A (2002) Activity-dependent regulation of dendritic growth and patterning. Nat Rev Neurosci 3:803-812.

Wu CS, Ballester Rosado CJ, Lu HC (2011) What can we get from 'barrels': the rodent barrel cortex as a model for studying the establishment of neural circuits. Eur J Neurosci 34:1663-1676.

Yanagisawa T, Tsumoto T, Kimura F (2004) Transiently higher release probability during critical period at thalamocortical synapses in the mouse barrel cortex: relevance to differential short-term plasticity of AMPA and NMDA EPSCs and possible involvement of silent synapses. Eur J Neurosci 20:3006-3018.

Yang JW, Hanganu-Opatz IL, Sun JJ, Luhmann HJ (2009) Three patterns of oscillatory activity differentially synchronize developing neocortical networks in vivo. J Neurosci 29:9011-9025.

Zhang LI, Poo MM (2001) Electrical activity and development of neural circuits. Nat Neurosci 4 [Suppl]:1207-1214.

Zhao C, Kao JP, Kanold PO (2009) Functional excitatory microcircuits in neonatal cortex connect thalamus and layer 4. J Neurosci 29:15479-15488

Zhuang X, Masson J, Gingrich JA, Rayport S, Hen R (2005) Targeted gene expression in dopamine and serotonin neurons of the mouse brain. J Neurosci Methods 143:27-32. 